\title{
PERSPECTIVE
}

\section{Pulmonary perspective: immunology in diagnosis and treatment of lung cancer}

\author{
P. Weynants*+, F-X. Marchandise*, Y. Sibille**
}

\begin{abstract}
Pulmonary perspective: immunology in diagnosis and treatment of lung cancer. $P$. Weynants, F-X. Marchandise, Y. Sibille. CERS Journals Ltd 1997.

ABSTRACT: The combination of the limits encountered with current therapies and the increased knowledge of immunology have opened perspectives for the use of immunomodulators in the management of lung cancer patients. Both humoral and cellular immunity are now evaluated in diagnosis and treatment of cancer.

Monoclonal antibodies (MoAbs) against tumour-associated antigens are now tested with various imaging techniques to improve detection and staging of lung cancer. MoAbs are also used in therapeutic clinical trials as: 1) mediators of immune effector function; 2) carriers of cytotoxic agents; 3 ) agents to block tumour growth factor; or 4) anti-idiotype vaccines.

Immune effector cells, such as natural killer (NK) cells, T- and B-lymphocytes, macrophages, dendritic cells and neutrophils, are present either within or around tumours and are likely to play a role in cancer. These cells, either alone or with cytokines, could provide new efficient therapeutic approaches, particularly if immunosuppression is involved in tumour progression. In this context, most recent studies using immune cells and molecular bioengineering, could provide additional antitumoral effects.

Finally, the discovery of several tumour rejection antigens has revived the dream of designing tumour vaccines and active specific immunotherapy. Eur Respir J 1997; 10: 1703-1719.
\end{abstract}

\author{
Correspondence: Y. Sibille \\ Pulmonary Section \\ UCL - Mont-Godinne \\ B-5530 Yvoir \\ Belgium
}

* Pulmonary Section, Dept of Internal Medicine, Université Catholique de Louvain, Yvoir, Belgium. + Ludwig Institute for Cancer Research and Experimental Medicine Unit, International Institute of Cellular and Molecular Pathology, Brussels, Belgium.

Keywords: Cytokines, immunotherapy, lung cancer, lymphocytes, macrophages, monoclonal antibodies

Received: December 101996

Accepted after revision March 311997

PW was supported by a grant from "La Fondation du Patrimoine de l'Université Catholique de Louvain".
With more than 600,000 new cases per year, lung cancer represents the most frequent lethal neoplasm in males, whilst its incidence increases progressively in females [1]. Despite considerable efforts, only $5-10 \%$ of these patients eventually survive 5 yrs after diagnosis and surgery accounts for the majority of these long-term survivors. Chemotherapy and radiation therapy sometimes provide beneficial responses in reducing tumour size and prolonging survival. However, only a small proportion of patients experience a complete response to therapy and remain disease-free. The recent availability of recombinant growth factors for bone marrow progenitor cells could reduce the haematological toxicity of drugs and radiation, hence providing an opportunity to apply more intensive regimens of cytotoxic agents [2]. Yet, the benefit provided by such intensification remains uncertain at present. In addition, recent techniques, such as laser therapy, phototherapy, brachytherapy, cryotherapy and endobronchial prosthesis, can often improve the comfort of cancer patients. These, however, represent supportive rather than curative treatments [3].

Considering the number of patients with nonresectable lung cancer and the disappointing results obtained with the current therapies, new therapeutic approaches are required. The purpose of this review is to discuss the recent progress achieved in the understanding of immunological events related to lung cancer, and to evaluate their relevance to practical applications, such as diagnosis and therapy.
The rationale behind the use of immunotherapy in cancer is based on the possibility of increasing the antitumour defences of the host. This approach was applied to lung cancer in 1972, when authors reported improved survival in lung cancer patients who developed postoperative empyemas as compared with noninfected patients, suggesting an adjuvant immunostimulatory effect of bacterial products [4]. These results raised the question: does immunotherapy in cancer enhance the immunocompetence of the host or the antigenicity of tumour cells, or both?

As early as 1957, BuRnet [5] suggested that tumour cells have antigenic properties and that the development of cancer was linked to a defect of the immune system, leading to an inappropriate tumour rejection response. However, immunosuppression is generally associated with advanced cancer and, therefore, it is uncertain whether the immune defects contribute to the development of the tumour or rather represent a consequence of tumour growth. Thus, both in vitro and in vivo immune responses have been found to be reduced in cancer patients [6]. The immunosuppressive response includes: a decrease of delayed type hypersensitivity reactions; abnormal distribution of T-lymphocyte subsets; reduced cytolytic activity of peripheral blood mononuclear cells; and impaired proliferative response of lymphocytes to various mitogens [7-10]. More recently, defects in cytokine production have also been reported in cancer patients $[6,10]$. 
The precise mechanisms of the immunosuppression still remain uncertain, but a multiplicity of factors have been postulated, including tumour-derived suppressor molecules, such as the transforming growth factor- $\beta$ (TGF$\beta$ ) and interleukin-10 (IL-10) [6]. By contrast, a number of studies have documented the activation of immune processes in patients with cancer, including lung carcinoma. In particular, the lymphocytes infiltrating the tumour appear to be activated, and high levels of interleukin-2 (IL-2) receptors are observed in the peripheral blood of patients with limited bronchial tumours when compared with patients with advanced disease [11, 12]. These receptors are considered to be important messengers for lymphocyte activation. Furthermore, patients whose preoperative peripheral blood lymphocytes demonstrated autologous tumour-killing activity (ATK (+)), survived significantly longer than ATK (-) patients [13, 14]. Altogether, it is reasonable to assume that, at an early stage of their disease, lung cancer patients are immunocompetent and that the immunocompetence decreases as the disease progresses. External factors, such as cachexia, chemo- and radiotherapy, are likely to contribute to the immunosuppression.

The counterpart of the immunocompetence of the host is the antigenicity and immunogenicity of cancer cells. This necessarily implies that cancer cells are not only "antigenic", i.e. express antigens, but that these antigens are also "immunogenic", able to be recognized and rejected by the immune system if appropriately presented and processed. However, it is clear that human tumours, at least those that are clinically detected, are not immunogenic and arise in immunocompetent patients. This does not mean that they cannot be antigenic. It is a longstanding dream of immunologists to demonstrate antigenicity and to identify the relevant antigens to render them immunogenic and induce tumour rejection. We will review the most relevant studies on the humoral (production of antibodies) and cellular immune response directed against lung cancer cells and their application in immunomodulatory clinical trials.

\section{Monoclonal antibodies (MoAbs) and passive immunotherapy}

Immunotherapy, with serum from immunized humans or animals, was first empirically tested in cancer at the beginning of this century [15]. Substantial drawbacks, in particular inconsistent and generally transient response associated with substantial side-effects, led to a progressive lack of interest in such therapy, until recently.

Circulating antibodies against autologous tumour cell proteins have been identified in lung cancer (LC) patients. Antibodies against p53 proteins have been detected in the sera of small cell lung cancer (SCLC) patients, and anti-HU, anti-JO and anti-RI neuronal antibodies have been identified in the serum of SCLC patients with neurological paraneoplastic syndromes $[16,17]$. One recent study confirmed that the sera of LC patients frequently contain antibodies against several tumour cell proteins, and in SCLC patients the presence of these circulating antibodies was associated with improved survival. Moreover, patients with limited disease were more likely to have such humoral response [18]. However, the epitopes recognized by these antibodies are not yet identified.

The generation of MoAbs with single antigenic specificity has provided new immunological tools for identification of antigens expressed in LC [19]. Throughout the past decade, numerous MoAbs have been generated against tumour cells, including LC cell lines, and three international workshops have reported on the detailed analysis of series of MoAbs against antigens of lung cancer [20-22]. Panels of MoAbs have been tested against biopsy specimens and cell lines both from SCLC and non-small cell lung cancer (NSCLC). These MoAbs have been classified into 15 different clusters, according to their pattern of reactivity (table 1). Antigenic targets for these antibodies include neural cell adhesion molecules (NCAM), carbohydrate antigens, high molecular weight mucins, or blood group-associated antigens. Some are highly specific for neuroendocrine cells, whilst others demonstrate cross-reactivity with epithelial cells. None of the antigens studied are either specific for LC subset or universally present on all LC specimens. These antigens recognize markers of differentiation rather than specific tumour markers, and therefore represent lung cancer-associated antigens (LCAAs) rather than tumour-specific antigens (TSAs) [23]. The function, as well as the biochemical nature, of these LCAAs remain so far largely unknown, with the exception of the cluster 1 antigen identified as the NCAM. The NCAM functions as a homophilic adhesion molecule involved in cell-cell interaction, and plays an important role in embryogenesis and cell differentiation [24]. Interestingly, NCAM expression by tumour cells from resected NSCLC was found to be associated with extension of the tumour to the mediastinal lymph nodes, and with shorter survival [25].

Several mechanisms of action by which MoAbs could target cancer have been proposed and tested. These include: 1) activation of immune determinants, such as complement or antibody-dependent cell-mediated cytotoxicity (ADCC); 2) interference with cell growth or differentiation by binding to constituents, such as growth factors or receptors, at the surface of tumour cells; 3 ) delivery of toxic agents, such as drugs, toxins and radionuclide conjugates; and 4) active immunization with a MoAb used as an anti-idiotype vaccine. In addition, bispecific MoAbs, which recognize a T-cell receptor and a tumour-associated antigen simultaneously, have also been generated.

MoAbs are used in numerous studies: 1) as reagents for immunoassays and immunohistological staining; and 2) for the delivery of imaging and therapeutic agents in cancer. So far, the majority of the studies concern animal models or established LC cell lines [26, 27]. Despite important information obtained with these models, results should be analysed with caution, since animal models as well as in vitro binding studies do not necessarily predict the efficacy of MoAbs in human trials. Phase I clinical studies were only recently initiated to evaluate the toxicity, the pharmacology and the biological effects of MoAbs.

In the following section, we will focus on some of the in vitro and in vivo studies using MoAbs raised against LC cells for diagnostic and therapeutic application. 
Table 1. - Clusters of lung cancer-associated antigens (LCAA) based on the analysis of the third international workshop

\begin{tabular}{|c|c|c|c|c|}
\hline Cluster & Antibodies & \multicolumn{2}{|l|}{ Antigen clusters } & Distribution \\
\hline \multirow[t]{2}{*}{1} & ITK2, Mab735, RNL-1 & & SCLC, carcinoid, neuroblastoma \\
\hline & MB-2, SEN36, SEN7 & \multicolumn{2}{|l|}{$\begin{array}{l}150 \mathrm{kDa} \text { membrane } \\
\text { glycoprotein }\end{array}$} & $\begin{array}{l}\text { Nerve, Striated muscle, thyroid epithelium, } \\
\text { NK cells }\end{array}$ \\
\hline \multirow[t]{2}{*}{2} & MOC-31, MOC-38, MOC-151, & \multirow{2}{*}{\multicolumn{2}{|c|}{$\begin{array}{l}\text { EGP-2/GA } 733-2 \\
40 \mathrm{kDa} \text { glycoprotein }\end{array}$}} & SCLC, carcinoid \\
\hline & $\begin{array}{l}\text { MOC-181, AUA 1, S-L 2.21, } \\
\text { probably PE-35 and S-L } 4.20\end{array}$ & & & $\begin{array}{l}\text { Wide distribution on normal and malignant } \\
\text { epithelial tissues }\end{array}$ \\
\hline 4 & $\begin{array}{l}\text { SWA } 21, \text { SWA } 22, \text { probably } \\
\text { SWA } 11\end{array}$ & \multicolumn{2}{|c|}{$\begin{array}{l}50 \mathrm{kDa} \text { glycosylated protein, } \\
\text { CD24 }\end{array}$} & $\begin{array}{l}\text { SCLC, carcinoid, neurobalstoma, NSCLC } \\
\text { Normal epithelial cells, granulocytes }\end{array}$ \\
\hline 5 & SWA 4, SWA 23, LAM 8 & \multicolumn{2}{|c|}{$90-135$ and $200 \mathrm{kDa}$} & $\begin{array}{l}\text { One half of SCLC } \\
\text { Little expression on normal epithelial tissues }\end{array}$ \\
\hline $5 \mathrm{~A}$ & $\begin{array}{l}\text { SEN31, SWA 20, probably } \\
\text { SEN } 3\end{array}$ & \multicolumn{2}{|l|}{$40-100$ and $180 \mathrm{kDa}$} & Coexpressed on SCLC with cluster 5 \\
\hline 6 & $\begin{array}{l}\text { MLucC-1, ABL364, } \\
\text { MLuc-5, KM132 }\end{array}$ & $\begin{array}{l}\text { sialoglycoprotein } \\
\text { Le } 7 \text { hapten }\end{array}$ & $\begin{array}{l}\text { Carbohydrate } \\
\text { antigens }\end{array}$ & \\
\hline w7 & NCC-ST-439, NCC-CO-450 & Sialoglycated LNFP111 & $\begin{array}{l}\text { Blood group } \\
\text { associated }\end{array}$ & $\begin{array}{l}\text { Broad epithelial reactivity (SCLC and } \\
\text { NSCLA) }\end{array}$ \\
\hline 8 & $\begin{array}{l}\mathrm{CC} 49, \mathrm{~B} 72.3, \mathrm{CC} 83,1.291 \\
2.304, \mathrm{~A}-80\end{array}$ & \multicolumn{2}{|l|}{ Mucin (TAG-72) } & \\
\hline 9 & $\begin{array}{l}\text { KL-6, KM432, CTM01, } \\
\text { ICR2 }\end{array}$ & \multicolumn{2}{|l|}{ Mucin MUC-1 } & $\begin{array}{l}\text { Broad epithelial reactivity } \\
\text { Blood cell }\end{array}$ \\
\hline 10 & RNL-2, RNL-3 & \multicolumn{2}{|c|}{$\begin{array}{l}134 \text { to } 25 \mathrm{kDa} \text { intracellular neuron- } \\
\text { specific proteins }\end{array}$} & Neuroendocrine tissues (SCLC) \\
\hline 11 & 44-3A6, KM195 & \multicolumn{2}{|c|}{$40 \mathrm{kDa}$ membrane-associated protein } & $\begin{array}{l}\text { NSCLC (lack of neural or white blood cell } \\
\text { reactivity) }\end{array}$ \\
\hline 12 & $\begin{array}{l}\text { MW207, FBP146, FBP343, } \\
\text { FBP458, FBP741 }\end{array}$ & \multicolumn{2}{|l|}{ Folic acid receptor } & NSCLC (adenocarcinoma) \\
\hline 13 & RS7, MR54 & \multicolumn{2}{|c|}{$\begin{array}{l}\text { Epithelial transmembrane } \\
\text { glycoprotein, EGP-1/GA 733-1 }\end{array}$} & NSCLC \\
\hline 14 & EMD5590, ICR16, ICR12 & \multirow{2}{*}{\multicolumn{2}{|c|}{ EGF receptor, p185 neu }} & NSCLC, mesothelioma \\
\hline 15 & ME-1, ME-2 & & & NSCLC (epidermoid), mesothelioma \\
\hline
\end{tabular}

NCAM: neural cell adhesion molecule; EGF: epidermal growth factor; SCLC: small cell lung cancer; NK: natural killer; NSCLC: non-small cell lung cancer. (Adapted from [22]).

\section{MoAbs in diagnostic application}

The development of immunohistochemical analysis using well-characterized MoAbs has revealed many hitherto unsuspected relationships between SCLC and NSCLC tumours. For instance, the incidence of neuroendocrine (NE) NSCLC tumours detected by immunochemistry, in particular among adenocarcinoma, ranges $10-30 \%$.

It has been suggested that the clinical behaviour of NE-positive NSCLC could differ from NE-negative NSCLC. Thus, in some studies, NE-positive NSCLC tumours have a higher overall response rate to systemic chemotherapy compared to NE-negative NSCLC, and appear to be associated with better median survival [28, 29]. However, in other studies, NE-positive NSCLC did not appear to be more sensitive to chemotherapy, and large prospective studies are required to settle the relevance of NE markers in NSCLC [30, 31].

Another diagnostic application of MoAbs is the early detection of LC in sputum. MoAbs against a glycolipid antigen of SCLC and a protein antigen of NSCLC were applied to preserved sputum specimens from individuals who participated in a multicentric study evaluating the efficacy of sputum cytology in lung cancer screening. This technique has allowed the recognition of neoplastic antigen expression 2 yrs before clinical diagnosis of cancer, with 90\% accuracy [32]. Similar techniques using MoAbs directed against oncogene products or growth factors are currently under investigation [33]. Thus, using a polymerase chain reaction-based assay, mutation of either $K$-ras or p53 gene has been identified in stored sputum obtained more than $1 \mathrm{yr}$ prior to clinical diagnosis of LC [34]. The clinical correlate could include early surgery or laser phototherapy in those newly detected in situ or microinvasive lung tumours. This, however, should be combined with the development of more sophisticated techniques to precisely localize such focal lesions [33].

One additional application is the use of MoAbs to detect bone marrow metastases. We and others have shown that $30-50 \%$ of SCLC patients, who otherwise had limited disease, had bone marrow micrometastases detectable only through immunodetection with one, or preferably a panel, of anti-SCLC MoAbs [35, 36]. The prognostic value of such detection remains uncertain, but could have considerable impact on the management of these patients in the context of high-dose chemotherapy with autologous bone marrow transplantation or peripheral haematopoietic stem cells rescue. Moreover, a recent report has shown that, in SCLC patients, immunocytological detection of residual marrow disease at otherwise clinical remission could predict metastatic relapse [37].

Radioimaging of lung tumours can be obtained in xenografted models with iodine-99, technetium-99 or indium111 radiolabelled MoAbs for tumour detection [38]. Recently, these radiolabelled MoAbs were introduced in human clinical trials. Most investigators use technetium-99, which appears superior in terms of availability, safety, cost and gamma-ray energy [39]. MoAbs 
recognizing a $40 \mathrm{kDa}$ glycoprotein expressed by most lung tumour cells have been used for locoregional staging of NSCLC tumour. A preliminary phase I study suggests that MoAb imaging could improve staging of the disease, in particular the evaluation of mediastinal lymph node infiltration by tumour, preventing invasive diagnostic techniques, such as mediastinoscopy. In that study, computed tomography (CT) and MoAb imaging were in agreement in $73 \%$ of the patients [40]. In a study on bronchogenic carcinoma, using photoscanning with indium-111-labelled MoAb against the carcinoembryonic antigen (CEA), immunoscintigraphy images correlated with tumour in-filtration in pathological specimens both from the primary and the secondary sites of the tumour [41]. This imaging technique appears particularly sensitive for brain metastases but yields poor sensitivity in liver and adrenal gland metastases. Interestingly, no correlation was observed between scanning and CEA serum levels or histotype.

More sophisticated techniques, such as single photon emission computed tomography (SPECT), could increase both performance and sensitivity of the radioimaging diagnosis. SPECT has recently been used in a phase I trial with anti-epidermal growth factor receptor (EGFR) $\mathrm{MoAb}$ in patients with squamous cell carcinoma, with promising results. Tumour was detected in all patients who received doses over $20 \mathrm{mg} \mathrm{MoAb}$, and metastases $\geq 1 \mathrm{~cm}$ in diameter were imaged with doses greater than $40 \mathrm{mg}$ [42]. Using SPECT and indium-111-labelled anti$\mathrm{CEA} \mathrm{MoAb}$ in preoperative staging of bronchogenic carcinoma, BUCCHERI et al. [43] obtained at least similar accuracy for lymph node assessment when compared to computed tomography. The authors suggest that, in some patients with nonsquamous bronchogenic carcinoma, the immunoscintigraphic technique could provide additional information, in particular for mediastinal lymph node evaluation. By contrast, another study comparing ${ }^{131}$ I-labelled anti-CEA and anti-carbohydrate antigenic determinant 19-9 (CA 19-9) immunoscintigraphy with computed tomography in the detection of mediastinal lymph node metastases in lung cancer, did not provide additional information to $\mathrm{CT}$ scan in noninvasive mediastinal staging of lung cancer [44]. Moreover, one major limitation of these techniques concerns small tumours (diameters $<3 \mathrm{~cm}$ ) and poor antigen expression, where false-negative results can be expected.

\section{MoAbs in therapeutic application}

MoAbs are investigated as therapeutic tools in four different applications: 1) mediators of immune effector function; 2) carriers of cytotoxic agents; 3) agents to block growth factors or their receptors; and, finally, 4) anti-idiotype vaccines.

Mediators of immune effector function. MoAbs directed against LCAA have been selected to mediate effector mechanisms, including complement-induced cytotoxicity and cellular cytotoxicity. For instance. a combination of antibody and human complement can be used for selective eradication of SCLC from bone marrow in vitro. We and others have reported successful in vitro purging of bone marrow micrometastases using a panel of complement-mediated MoAbs [45, 46]. More recently, a phase I/II study using the MoAb ABL364 directed against the cluster 6 antigens has been initiated in refractory SCLC [47]. This MoAb is able to eradicate SCLC cell lines in vitro by complement-dependent cytotoxicity. If this type of therapy proves to be efficacious, it will provide alternative treatments for tumours resistant to conventional therapy. Unfortunately, so far no clinical response has been documented.

Immunoconjugates. Clinical trials with naked MoAbs, i.e. nonconjugated with drugs, toxins or isotopes, have generally demonstrated limited response, if any. In part, the explanation resides in the observation that most murine antibodies do not activate human effector cells or have direct cytotoxic effects [48]. Moreover, the cytotoxicity of MoAbs was only demonstrated in vitro in conditions where MoAb, complement or effector cells were present in large excess [49]. To increase their biological activity, MoAbs were then used as vehicle for site-directed delivery of toxic substances. These immunoconjugates tested in vitro demonstrated their potential value in therapy. Thus, effective treatment of SCLC xenografts with ${ }^{131}$ I-labelled MoAb has been reported [50], as well as the in vitro antiproliferative action of conjugates with ricin A chain $[51,52]$. Ricin is a plant toxin, and is now frequently used in conjugation with antibodies directed against tumour.

A blocked ricin immunoconjugate N901-bR (an antiNCAM MoAb) (CD56), has recently been evaluated against relapsing SCLC. The preliminary phase I study demonstrated a partial response in one patient, and further studies are currently under way [53]. Recently, antibody-targeted liposomes were found to successfully deliver cytotoxic drugs specifically to SCLC xenografts, while bispecific antibodies comprised of anti-SCLC $\mathrm{MoAb}$ and anti-effector cell MoAb were able to mediate in vitro killing of tumour cells by interferon- $\gamma$ (IFN$\gamma$ )-activated monocytes [54]. Preclinical studies have documented an antitumour effect of antibody-drug conjugates in lung adenocarcinoma and squamous cell carcinoma [55]. These reports indicate significant tumour regression compared to free drug or free MoAb administered either singly or in combination.

These preliminary results are encouraging and should now be evaluated in clinical trials.

MoAb antigrowth factor. Growth factors, such as neuropeptides, cytokines and polypeptides, represent a heterogeneous family of signalling molecules, which are essential for cell proliferation. These molecules are implicated in physiological processes, such as embryogenesis, haematopoiesis, wound healing and immune response $[56,57]$.

The ability of cancer cells to produce, secrete and respond to several growth factors has become a central theme for studying the mechanism of growth regulation of tumour cells. Several of such autocrine growth factors have been described in SCLC and NSCLC [56-58]. Bombesin/gastrin-releasing peptide (GRP), insulin-like growth factor-1 (IGF-1) or somatomedin and transferrin have been identified as growth factors in SCLC, whilst EGF, IGF-1 and transforming growth factor alpha $(\mathrm{TGF}-\alpha)$ are involved in NSLC cell proliferation [58]. A better knowledge of their mechanism of action could provide us with alternative therapeutic approaches in the 
management of patients with LC. These include: the use of MoAb directed against growth factors and/or against their receptors; the use of polypeptide antagonist for growth factors; and, finally, disruption of the signal pathway after internalization of these factors within cells.

Preclinical studies have clearly shown that a MoAb (2A11), with specificity for the carboxy-terminal portion of bombesin, is able to block the binding of bombesin/GRP to its receptor and to inhibit the clonal growth of SCLC cell lines in vitro. The growth of some SCLC xenografts can be significantly inhibited by this MoAb [59]. Unfortunately, these interesting observations have not been further documented using other cancer cell lines. Nevertheless, preclinical phase I/II studies using the injection of MoAb anti-GRP have recently been started at the National Cancer Institute. So far, only low doses have been used and, with the exception of one patient, no evidence of objective tumour regression in advanced SCLC patients has been observed [60, 61]. Among other MoAbs against tumour growth factors, MoAbs directed against the EGFR conjugated with ricin A chain have also been found to be selectively cytotoxic for NSCLC tumours when injected into nude mouse/xenografts [62].

More recently, Divgi et al. [42] reported a preliminary phase I study with a labelled anti-EGFR MoAb in patients with squamous cell LC. Despite encouraging preliminary results, several drawbacks are likely to interfere with optimal response. Firstly, it is uncertain whether the antibody penetration into the tumour bed is adequate; and, secondly, it is likely that a particular tumour produces and responds to more than one single growth factor, underlying the necessity for a panel of antigrowth MoAbs. Finally, the heterogeneity of lung tumours suggests that no single antiproliferative agent will be curative [57].

One additional way to block the growth factor loops is the use of polypeptide antagonists. These antagonists bind to a specific (autocrine) receptor without producing the conformational changes that trigger the biological response. Peptide antagonists of the mitogenic effects of bombesin have been characterized [63]. These molecules are potentially less immunogenic and have a better tissue penetration compared to MoAbs. However, SCLCs represent a complex group of tumours, whose growth is regulated by multiple and potentially different autocrine and paracrine interactions, and agents directed against single factors will probably have a limited efficacy. By contrast, large spectrum neuropeptide antagonists are now available, and appear to represent more effective antiproliferative agents in SCLC. Among these agents, neuropeptide antagonists $\mathrm{D}$ and $\mathrm{G}$ have been demonstrated to block multiple autocrine and paracrine loops [63]. These broad spectrum antagonists can inhibit the basal and stimulated clonal growth of many SCLC cell lines regardless of positivity for bombesin receptors, suggesting that these antagonists could be more useful anticancer drugs than ligand-specific growth factor antagonists [64]. This has been further documented in a mouse xenograft tumour model [65].

In addition to positive growth factors, physalaemin and somatostatin can be considered as negative growth factors for SCLC [66]. Although not cytotoxic, they could be complementary to debulking chemotherapy.
For instance, somatostatin receptors are present on half of the primary SCLCs, and one group has reported growth reduction of a SCLC cell line in vitro, as well as in vivo tumour regression in the presence of a somatostatin analogue $[67,68]$. Administration of a somatostatin analogue, such as octreotide, could be associated with antitumour activity in neuroendocrine neoplasm [69, 70].

Finally, the elucidation of signal transduction pathways has identified a number of intracellular messengers, such as protein kinase $\mathrm{C}, \mathrm{G}$ protein and oncogenes, used by many mitogens. These messengers represent targets for novel therapies, and possible therapeutic strategies might include the development of antibodies or antisense oligonucleotides to these oncogenes, with novel methods of delivering drugs intracellularly. For example, the downregulation of $K$-ras expression by transfection with antisense ribonucleic acid (RNA) construct has been shown to inhibit the growth of a human NSCLC cell line [71].

Anti-idiotype vaccine. The immunization of patients with anti-idiotypic antibodies (Ab2) that carry the functional image of tumour antigens (TA) can elicit an immune response mediated by anti-anti-idiotypic antibodies (Ab3) directed against the tumour carrying the corresponding antigen, and this represents an alternative approach for specific immunotherapy in patients with cancer [72] (fig. 1). Previous studies in animal models have demonstrated the validity, as well as the efficacy, of immunization with Ab2 to induce immunity against tumour cells [72]. Clinical trials with Ab2 anti-TA are currently ongoing in patients with colorectal carcinoma and melanoma, and a preliminary report in advanced melanoma suggests clinical response, with increased survival [72-74]. These studies have documented that Ab2 could be

a)

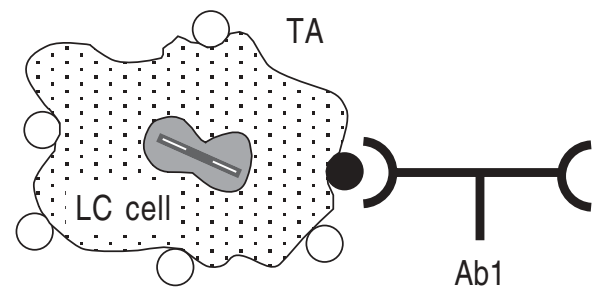

b)

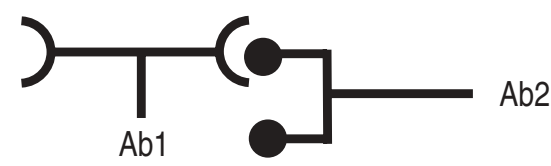

c)

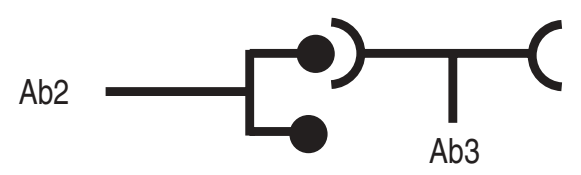

Fig. 1. - Schematic presentation of the idiotypic cascade. a) The first antibody (Ab1) is produced through immunization of the mouse with lung cancer (LC) cell. Ab1 recognizes a tumour-associated antigen (TA). b) In a second step, immunization of the mouse with this Ab1 generates the production of anti-idiotype antibody, or second antibody (Ab2), mimicking the TA that is bound by the Ab1. c) This anti-idiotype Ab2 can, thus, serve as a surrogate antigen for vaccination of the patient to induce the in vivo production of anti-anti-idiotype antibody (Ab3), with antitumour specificity. 
administered safely, and that Ab3 response could be achieved in vivo and associated with occasional tumour responses [73, 74]. In this regard, monoclonal Ab2s elicited with a MoAb against a cluster 5 and $5 \mathrm{a}$ antigen (TA sialoglycoprotein) have recently been reported [75, 76]. Their injection in mouse and rat species produces an Ab3 response effective against SCLC cell lines sharing the cluster $5 \mathrm{a}$ antigen. One of these Ab2 antibodies, LY8-229, was found to be the most effective in inducing an $\mathrm{Ab} 3$ response. In addition, an idiotype-specific antibody reactivity was recently reported against this Ab2 in the sera of SCLC patients. This suggests that this Ab2 (LY8-229) represents a nominal SCLC antigen and, therefore, should be a candidate for active immunotherapy in SCLC patients [77].

Active immunotherapy with Ab2 antibodies has several theoretical advantages when compared to passive immunization with Ab1 [72]: 1) lower doses are required; 2 ) the stimulated immune cells cross the endothelial barrier and reach the tumour more easily; and 3) this type of immune response could generate permanently activated immune B- and T-cells. Nevertheless, several questions are raised, including whether the ability of anti-idiotypic antibodies to elicit immunity against the corresponding TA in an animal species represents an appropriate criterion to select a therapeutic agent for human cancer. Moreover, it is questionable whether the development of antibodies to xenogenic immunoglobulins (Ig) would not lead, with time, to a reduction of the immunizing effect of repeated injection of Ab2 antibodies.

Progress in molecular biological techniques could also provide new approaches for anti-idiotypic immunotherapy. For instance, messenger ribonucleic acid (mRNA) sequence analysis of the "internal image" of murine monoclonal anti-idiotypic antibodies may identify the region of sequence critical to antigen mimicry. Therefore, peptides corresponding to these sequences could pro- vide useful reagents for synthetic vaccines in active immunotherapy against tumour antigens (TA) [72, 73].

In summary, with the advances in MoAb technology, new approaches for therapy of LC are now available. Preclinical studies have demonstrated the potential therapeutic effects of these agents in in vitro and in vivo models, but several problems need to be solved before clinical therapeutic benefits can be achieved [78]. These include: 1) cross-reactivity with normal tissue; 2) inadequate tumour penetration; 3 ) heterogeneity of antigen expression, antigenic modulation; 4) the development of a human antibody response against the mouse monoclonal protein; and 5) discovery of true specific tumoral antigens. Some developments could circumvent these limitations. For instance, peptides corresponding to the sequence of internal image of murine monoclonal antiidiotypic antibody will hopefully be obtained by molecular biological techniques, leading to synthetic vaccine for active immunotherapy against lung cancer.

\section{Immune cells of tumour cytolysis and cytokine- adoptive therapy}

The cellular immune response against tumour can be mediated by four types of cell: natural killer (NK) cells; lymphokine-activated killer (LAK) cells; cytolytic Tlymphocytes (CTL); and activated macrophages [79] (fig. 2). Very recently, the important role of adhesion molecules in this immune response has been documented.

\section{NK cells}

NK cells represent a third lineage of lymphocytes in addition to T- and B-cells [80]. They are not targetspecific, but exhibit a more potent cytotoxic activity against tumour cells and virus-infected cells than normal cells in the absence of prior sensitization. The most

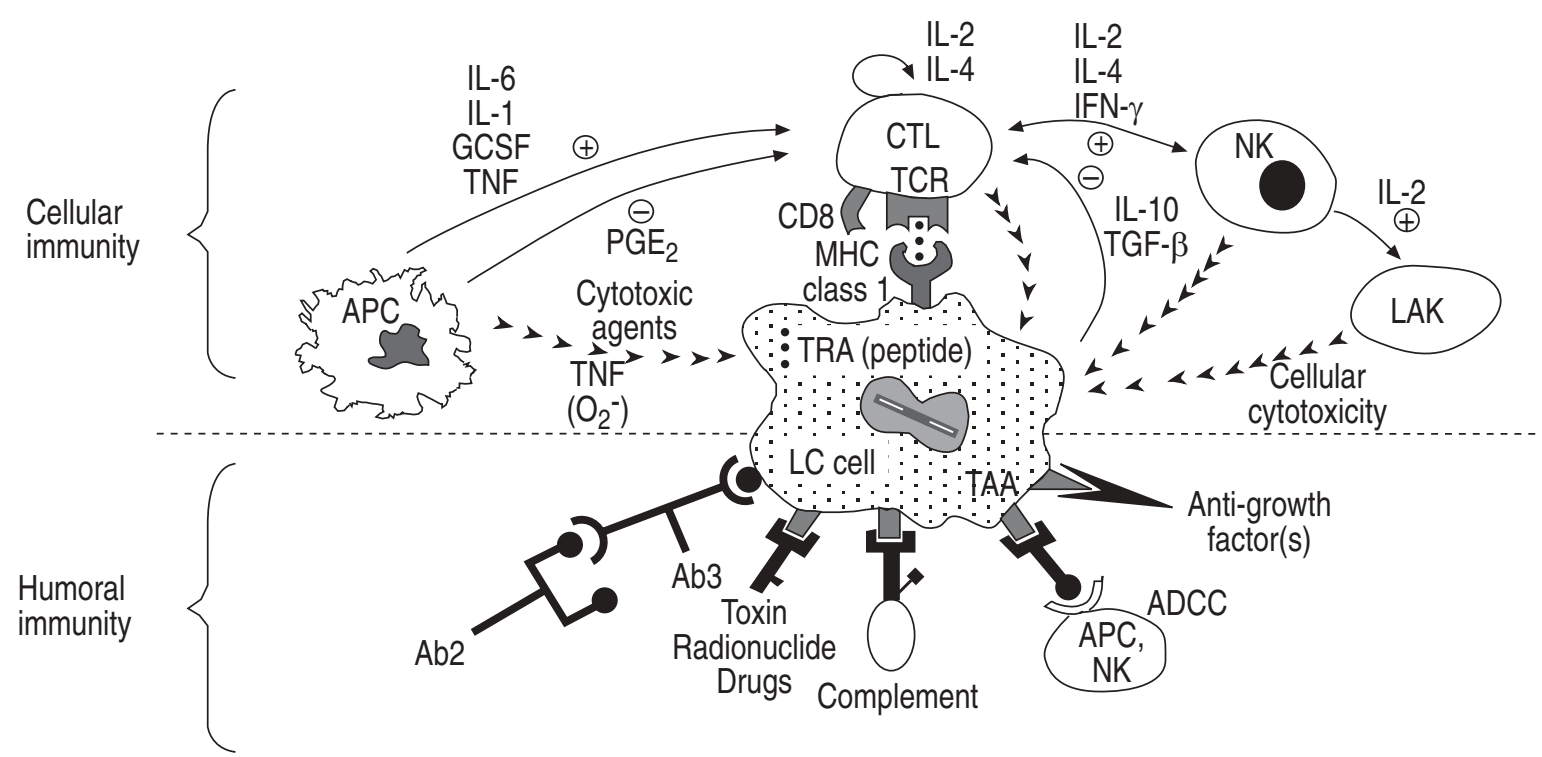

Fig. 2. - Potential mechanisms for lung cancer (LC) cell killing by monoclonal antibody reagents and immune cytolytic cells. The figure represents the potential effectors involved both in cellular and tumoral host immunity that could be involved in tumour cell killing and could potentially be targeted in immunotherapy of lung cancer. CTL: cytolytic T-lymphocytes; TCR: T-cell receptor; MHC: major histocompatibility complex; NK: natural killer cells; LAK: lymphokine-activated killer cells; APC: antigen-presenting cells; TRA: tumour-rejected antigen; TAA: tumourassociated antigen; ADCC: antibody-dependent cell-mediated cytotoxicity; IL: interleukin; IFN- $\gamma$ : interferon- $\gamma$; TGF- $\beta$ : transforming growth factor- $\beta$; GCSF: granulocyte colony-stimulating factor; TNF: tumour necrosis factor; $\mathrm{PGE}_{2}$ : prostaglandin $\mathrm{E}_{2}$; Ab2: anti-idiotype antibody (second antibody); Ab3: anti-anti-idiotype antibody. 
sensitive and widely used target cell for human NK cells is $\mathrm{K} 562$, a cell line derived from a chronic myeloid leukaemia. Phenotypically, NK cells are large granular lymphocytes that do not express $\alpha / \beta$ or $\gamma / \delta$ T-cell receptors or CD3 on their surface. NK cells are present in the peripheral blood of normal individuals and cancer patients and mediate non-major histocompatibility complex (MHC)-restricted cytotoxic activity. The majority of NK cells possess low affinity receptors for the Fc portion of immunoglobulin $\mathrm{G}$ ( $\mathrm{IgG}$ ) and are, therefore, also able to mediate ADCC. Interestingly, the cytotoxic activity of NK cells is rapidly enhanced by interleukin2 (IL-2) and the three types of interferon. In addition to cytotoxic activity, NK cells produce various lymphokines, such as IFN- $\gamma$, tumour necrosis factor (TNF) and granulocyte/macrophage colony-stimulating factor (GM-CSF). However, there is so far no convincing evidence that NK cells play a significant role in surveillance against LC, even though they are particularly effective in lysing targets devoid of MHC class I molecules. Moreover, despite the fact that peripheral blood from patients with large tumours or advanced cancer exhibit a reduced NK cell activity, attempts to correlate low NK cell activity with tumour development have not been successful $[81,82]$. Finally, conflicting results have been reported concerning pulmonary NK cells in patients with LC $[83,84]$. Discrepancies in these reports could be due, in part, to different sampling compartments: WeISSLER et al. [83] reported a reduction of NK cell activity of cells obtained from lung tissue, whereas PITCHENIK et al. [84] found an increase in NK function of cells recovered from the lavage fluid [85].

\section{LAK cells}

Culture of leucocytes with high doses of IL-2 for a few days induces the generation of a broadly reactive cytotoxic population able to lyse not only target cells sensitive to NK cells but also those that are resistant, such as fresh tumour cells. These effector cells have been designated lymphokine-activated killer (LAK) cells [86]. It is now clear that LAK cell activity is primarily mediated by IL-2-activated NK cells. Both SCLC and NSCLC cell lines are sensitive to LAK cell activity [87, 88]. LAK cells are usually derived from peripheral blood but lymph node and tumour infiltrating lymphocytes represent an additional source of LAK cells [89-91] as well as pleural cells.

\section{Specific cytotoxic T-lymphocytes (CTL)}

In mice, T-lymphocytes were shown to be the cells of the immune system that constitute the specific component of tumour rejection responses, and that carry long-term memory of tumour rejection response. The observation that tumour cells that escaped rejection in vivo were resistant to antitumour CTL demonstrated that the antigens recognized in vitro by the CTL could be effective targets in vivo [92]. It is now a common observation that T-lymphocytes of cancer patients can be stimulated in vitro to produce CTL that show specificity for autologous tumour cells [93]. These CTL are mostly CD8+ T-lymphocytes and recognize antigen presented by MHC class I molecules. Most of the antitumour CTL clones that specifically recognize the autologous tumour cells, in so far as they do not lyse autologous EpsteinBarr virus (EBV)-transformed B-cells or K562 cells (the prototype target of NK-like cytolytic effector cells), have been generated against melanomas [94]. Peripheral blood lymphocytes are the major source of lymphocytes for study of antitumour CTL, but CTL have also been generated from invaded lymph node, malignant pleural effusions and tumour-infiltrating lymphocytes (TILs) [95]. Gene transfection was used to identify the genes that encode the tumour rejection antigens (TRAs) recognized by such antitumour CTL [96].

The genes that have been identified so far fall into three groups [97]. A first group includes genes such as $M A G E-1, M A G E-3, B A G E$ and $G A G E$, which are not expressed in the normal tissues, except testis, but are expressed in significant proportions of different types of tumours, including NSCLC and SCLC [98-103]. A second group comprises genes encoding tyrosinase, Mela-AMART-1, gp $^{100}$ Pmel17, and $\mathrm{gp}^{75}$, which are only expressed in melanocytes and in melanoma cells [104108]. The third group contains genes that are mutated in tumour cells, such as MUM-1, CDK-4 or HLA-A2 molecules [109-111].

In lung cancer, oligoclonal T-cell populations isolated either from TIL or draining lymph nodes of advanced NSCLC can be expanded in vitro in the presence of IL2 , and have the ability to lyse autologous cancer cells [112-114]. Some, MHC class I-restricted CTL lines or clones that show specificity for autologous NSCLC cells or SCLC cells have been obtained from peripheral blood lymphocytes. Their target antigens have yet to be identified [115-118]. However, CTL derived from lymphocytes infiltrating NSCLC were shown to recognize a peptide encoded by the HER2-neu gene and presented by HLA-A2 molecules [119]. This gene is overexpressed in several types of tumour, including NSCLC and ovarian cell lines.

Cytokines associated or not with adoptive immunotherapy (table 2)

The discovery that immune cells produce cytokines involved in regulation of the immune response, and the ability to produce large quantities of the human cytokines by recombinant techniques, has expanded their use as potential anticancer agents. The effects of IL-2 and IFNs, either alone or in combination with immune cells, other cytokines or cytostatic agents, have been studied in lung cancer.

IL-2 promotes the growth of activated lymphocytes, increases their cytolytic activities against tumour cells and induces the generation of LAK cells, which are cytotoxic against autologous, syngenic and allogenic tumour cells [86]. IL-2, alone or in combination with LAK cells or TIL, was found to produce encouraging results in melanomas and renal cell carcinomas [120, 124, 129]. However, in advanced lung cancer patients, the results obtained with adoptive immunotherapy (high doses of IL-2 alone or in combination with LAK cells or TIL) were found to be disappointing. Thus, in patients with advanced SCLC who did not achieve a complete response after chemotherapy, IL-2 infusion could induce either complete remission or additional tumour regression in 
Table 2. - Results of phase I/II studies of cytokine (IL2, IFN) in LC combined or not with immune cells

\begin{tabular}{|c|c|c|c|c|}
\hline Histology & $\begin{array}{c}\text { Pts } \\
\mathrm{n}\end{array}$ & Agents & Results & [Ref.] \\
\hline Advanced & 1 & IL-2 alone & NR & [120] \\
\hline \multirow[t]{9}{*}{ NSCLC } & 5 & IL-2/LAK & NR & [120] \\
\hline & 1 & IL-2/IFN- $\alpha$ & NR & [121] \\
\hline & 11 & IL-2/LAK & $1 \mathrm{PR}$ & [121] \\
\hline & 16 & IL-2/TNF- $\alpha$ & $\begin{array}{l}1 \mathrm{PR} \\
3 \mathrm{MR}\end{array}$ & [122] \\
\hline & 11 & IL-2/IFN- $\alpha$ & NR & [123] \\
\hline & 5 & $\begin{array}{l}\text { IL-2/IFN- } \alpha \\
\text { continuous infusion }\end{array}$ & $1 \mathrm{PR}$ & [124] \\
\hline & 11 & $\begin{array}{c}\text { IL-2 } \\
\text { continuous infusion }\end{array}$ & NR & [125] \\
\hline & 8 & $\begin{array}{l}\text { IL-2 intralesional } \\
\text { + systemic }\end{array}$ & 2 PR & [126] \\
\hline & 11 & IL-2/TIL & NR & [127] \\
\hline SCLC & 24 & IL-2 postchemotherapy & $5 \mathrm{OR}$ & [128] \\
\hline
\end{tabular}

IL-2: interleukin-2; IFN: interferon; LC: lung cancer; NSCLC: non-small cell lung cancer; SCLC: small cell lung cancer; LAK: lymphokine-activated killer cell; TNF- $\alpha$ : tumour necrosis factor- $\alpha$; TIL: tumour-infiltrating lymphocytes; NR: no response; PR: partial response; MR: minor response; OR: objective response.

almost $20 \%$ of cases [128]. By contrast, marginal responses were achieved in patients with advanced NSCLC, a majority experiencing severe toxicity [120-127]. However, the therapeutic response appears to vary according to the anatomical site, suggesting a difference in susceptibility according to the location of the tumour. Thus, in LC patients, pleural infusion of IL-2 induced the disappearance of malignant effusion [130], or objective tumour response in 10 out of 22 patients [131].

Several issues regarding IL-2 in cancer therapy remain unclear. Firstly, the advantages of continuous versus bolus administration of IL-2 is still a subject of controversy. Also, IL-2 administered at lower doses in order to eliminate the vascular leak syndrome has been demonstrated to have similar antitumoral efficacy. Moreover, it remains uncertain whether the administration of LAK cells plus IL-2 provides a therapeutic benefit compared with IL-2 alone [120]. The mechanism of response and the reasons for variable response to immunotherapy within groups of patients with similar disease is not clear. PARMiani [132] proposed that successful adoptive immunotherapy is more dependent on the recruitment of activated host antitumour specific CTL than on the presence of LAK cells. Therefore, we could hypothesize that the number of circulating T-cells specific against LC cells is too low to provide a sufficient number of specific antitumour effector cells for adoptive immunotherapy. Furthermore, the majority of clinical trials have been noncomparative phase I or II studies, including patients with advanced refractory LC. This represents a major limitation to the appropriate evaluation of the efficacy of immunotherapeutic agents, since evidence from animal models and clinical experience has indicated that immunotherapy will best benefit cancer patients at an early stage of the disease, with minimal tumour burden. Two recent studies have evaluated the feasibility and efficacy of IL-2/LAK or IL-2/TIL as adjuvant therapy after resection of locally advanced LC [133, 134]. KIMURA and YAMAGUCHI [133] reported that the 7 year survival rate was greater in the immunotherapy group than in the control group (39 vs 12.7\%).

IFNs are a family of three $(\alpha, \beta$ and $\gamma)$ cytokines demonstrating potent antiproliferative and immunomodulatory activities. Although these mediators have proved to be effective in some malignancies, their activity in NSCLC seems to be rather marginal [135-138]. In SCLC, a recently published phase III study did not confirm the positive role of IFN- $\alpha$ and IFN- $\gamma$ as maintenance therapy in complete responder patients [139, 140]. However, complete tumour responses were observed after intrapleural injection of IFN- $\gamma$ in stage I and II mesothelioma patients [141]. In addition, an in vitro study suggested that IFN could potentiate the cytotoxic effect of cisplatin, but here again, despite encouraging phase II clinical studies, IFNs offered no survival benefit over chemotherapy alone in phase III studies [142-145].

\section{Macrophages and polymorphonuclear neutrophils}

The relevance of macrophages in cancer is supported by recent reports documenting that the majority of tumour-infiltrating cells are in fact macrophages [146]. The precise role of these macrophages needs, however, to be clarified. The mononuclear phagocytes and, in particular, the tumour-associated macrophages (TAMs) are often considered to be major defenders of the host against tumours, but there is now evidence that TAMs can also promote tumour growth [147]. TAMs, including lung macrophages, contain several secretory products that are potentially toxic for tumour cells, and among these products, oxygen metabolites, IFN- $\alpha$, TNF$\alpha$, IL- 1 and IL- 6 have been most thoroughly investigated. In addition, macrophages can also play an indirect role in the antitumoral immune response through the recruitment and activation of leucocytes to the tumour site.

In vitro, alveolar macrophages (AMs) recovered by bronchoalveolar lavage (BAL) from healthy subjects or noncancer patients, are spontaneously cytotoxic for tumour target cells, suggesting that human AMs are constitutively primed in vivo for this cytotoxic activity [148-150]. Thus, several agents, including lymphocyte and macrophage secretory products, were shown to "prime" the macrophage and to increase its cytotoxic activity [150-152]. These factors include cytokines (IFN$\delta$, IL-2, IL-4), macrophage and granulocyte/macrophage colony-stimulating factors (M- and GM-CSF), bacterial products (lipopolysaccharide (LPS), muramyl dipeptide) and pharmacological agents (phorbol esters, calcium ionophores) [153]. Once primed, macrophages exert their cytotoxicity either by cell-to-cell contact, with discharge of lysosomal enzymes, or through the release of cytotoxic effector molecules, such as reactive oxygen metabolites, IL-1, IL-6, TNF- $\alpha$ and C3a.

In addition, AMs can kill sensitized tumour cells through their Fc $\gamma$ receptors, which trigger an ADCC. In vitro studies have shown that AMs from NSCLC patients had a reduced cytotoxicity against tumour target cells but produced increased amounts of TNF- $\alpha$ and IL-1, suggesting that cytotoxic activities other than these two cytokines are deficient [154]. This, however, is in contrast with data obtained by other groups, including our own, demonstrating a decreased production of cytotoxic mediators (IL-1, TNF- $\alpha, \mathrm{O}_{2}$ ) by AMs from cancer 
patients compared to healthy volunteers $[155,156]$. This could result in a decreased tumoricidal activity, and has supported basic and clinical trials aiming to activate macrophage function [154]. Such efforts to activate the tumoricidal properties of macrophages in vivo with lymphokines, including IFN- $\gamma$, have so far produced disappointing results. Part of this failure is probably related to the extremely short life of lymphokines and to their nonspecific binding to cells or matrix components in tissues outside the tumour.

Several studies have documented in vitro the limited response of AMs from lung cancer patients to various stimuli, including IFN- $\gamma$ and GM-CSF [154, 157]. More recently, synthetic macrophage activators, such as muramyl di- or tripeptide (MDP or MTP), were entrapped within liposomes in order to prolong their life and improve their targeting [158]. The liposomes injected intravenously are cleared from the circulation by phagocytic cells. These cells reach the tumoral tissue at a selectively stimulated stage, hopefully to deliver their cytotoxic activity locally. Phase I clinical studies using intravenous liposome-encapsulated MTP demonstrated that antitumoral properties of blood monocytes from cancer patients were upregulated, but no significant reduction in tumour size could be observed. This again suggests that systemic macrophage activation could be effective at an early stage of the disease, characterized by a limited extension of the tumour and a large number of tumoricidal macrophages infiltrating the tumour.

The role of the tumour cells in the control of the macrophage response appears equally important. The cell type, stage of differentiation, surface antigens and secretory products of the tumour can influence macrophage functions. Among these secretory products, IL-10 and TGF- $\beta$ are potent immunosuppressive agents for macrophages. In addition, TGF- $\beta$ is a fibroblast activator and, therefore, could participate in the remodelling of the extracellular matrix during the process of tumour progression. Macrophages can also contribute to fibrin deposition within the matrix through the expression of procoagulant activity (PCA). Interestingly, PCA has been shown to be increased in AMs from patients with primary lung cancer [147, 159]. Together with matrix changes, angiogenesis represents a key factor in tumour growth and metastasis. Recently, interleukin-8 (IL-8), a chemokine produced in substantial amounts by macrophages and various tumour cells, was found to have a major angiogenic activity [160]. This angiogenic activity appears critical for the tumour growth, since, in an animal model of NSCLC, blocking antibodies against IL-8 were able to inhibit tumour angiogenesis and to reduce the tumour size by almost $50 \%$ [161].

These results are puzzling in the context of the other activities of IL-8. In particular, IL-8 is a potent chemotactic factor for neutrophils [162], but can also inhibit neutrophil extravasation when present in high intravascular concentrations. The role of neutrophils in the defence against cancer is poorly documented, although the ability of polymorphonuclear neutrophils (PMNs) to kill tumour cells in vitro by oxidative and nonoxidative mechanisms, such as defensins and cathepsin G, has been demonstrated [163]. Neutrophils are often the first host cells to infiltrate the tumour, and can elicit the influx of the secondary effector cells, such as macro- phages, NK cells and CTLs, into the tumour bed and possibly participate in their activation. A recent in vivo study using mammary adenocarcinoma cells engineered to produce various cytokines has underlined the important role of PMNs together with suppressor lymphocytes in the rejection of the tumour [164]. Altogether, the following hypothesis can be proposed: if appropriately secreted, IL-8 could, at an early stage, recruit neutrophils to reject the tumour cells. By contrast. at a later stage, increased amounts of IL- 8 produced in the tumoral tissue by tumour cells, phagocytes and neutrophils could leak into the vascular bed, promoting angiogenesis and blocking neutrophil migration, thereby promoting tumour progression.

Nevertheless, these subtle effects of IL- 8 underline the importance of timing in the therapeutic approach to cancer. The sequence of events should be carefully analysed before initiating clinical trials with immunoregulators and/or bioengineering, considering that several agents appear to have a potential dual activity, sometimes promoting and sometimes inhibiting tumour growth.

\section{Adhesion molecules}

Together with angiogenesis, the adhesion molecules play a critical role in the interaction of the tumour with the host $[165,166]$. Adhesion molecules are present on cancer cells and find their counterpart analogues on epithelial, endothelial and mesothelial cells, on extracellular matrix components, as well as on leucocytes.

At the tumour level, molecules such as cadherins are involved in the attachment and detachment of cancer cells from the primary tumour site [166]. In addition to cadherins, a series of adhesion molecules, such as sialyl carbohydrates, integrins, neural cell adhesion molecules (NCAMs) and protein tyrosine phosphatases, have been identified on tumour cells, with a growing interest in their functions beyond adhesion.

The $\beta$ family of integrins represents a group of heterodimeric adhesion glycoproteins. The $\beta 1$ integrins, including very late activation antigen (VLA-4), and $\beta 3$ integrins are present on tumour cells. They bind to endothelial cells and to matrix components, such as collagen, laminin and fibronectin [167]. These integrins also participate in differentiation and proliferation processes. Moreover, their surface expression appears to correlate with the degree of tumour invasion. The $\beta 2$ integrins are expressed mainly on the surface of leucocytes and, with intercellular adhesion molecules (ICAMs), vascular cell adhesion molecules (VACMs) and selectins, regulate the intravascular adherence and extravasation of these cells.

Recently, a member of the membrane-associated protein tyrosine phosphatases, the "secreted protein, acidic and rich in cysteine" (SPARC) has been shown to contribute to the tumorigenicity of human melanoma cells injected into mice [168-170]. Thus, the suppression of SPARC by molecular manipulation (SPARC antisense expression vector) reduces the in vitro adhesive and migratory properties of melanoma cells as well as their in vivo proliferation. Interestingly, recent studies in lung cancer also support the role of tyrosine phosphorylation in tumorigenesis. Thus, one report demonstrated that 
tyrosine phosphorylation used in vitro is a mitogenic signal in SCLC, while another study found a good correlation between the presence of tyrosine phosphorylated proteins in resected lung tumours and tumour relapses after surgery [170, 171].

While adhesion molecules are likely to participate in the process of tumour progression, it is also evident that they mediate the antitumoral response of the host. For example, adhesion molecules are implicated in the cellto-cell contact between tumour cells and LAK or NK cells. Thus, a recent report demonstrated that ICAM-1 was expressed spontaneously by NSCLC cell lines and by IFN- $\gamma$-stimulated SCLC cell lines [172]. Together with other cell adhesion molecules, ICAM- 1 could facilitate the binding of tumour cells to LAK cells.

The interaction of NK cells with tumour cells involves, at least partly, the binding of the CD95 (Fast/APO-1) receptor present on the tumour cell by the CD95 ligand present on NK cells [173]. The activation of the CD95 will result in apoptosis, or programmed cell death, of the tumour cell. In addition to the induction of apoptosis, the CD95 ligand in its soluble form has recently been shown to induce tumour rejection in vivo [174]. The latter activity is mainly dependent on neutrophils and to a lesser extent on CD8+ lymphocytes.

In summary, adhesion molecules are now recognized not only for their adhesive properties but also for a much larger regulatory function in tumour differentiation, growth and invasion. Trials using recombinant proteins, receptor agonists and antagonists, and monoclonal antibodies could give rise in the near future to alternative strategies for downregulating tumour progression and stimulating the antitumoral host defence.

\section{Pleural space}

Malignant pleural effusion (MPE) represents the most accessible site for the study of antitumour immune response. The influx of cells into the pleural space is a hallmark of neoplastic effusion. The understanding of the mechanism whereby cells are recruited from the peripheral circulation into the pleural space will be of therapeutic value. Thus, in MPE, lymphocytes and mononuclear phagocytes are the predominant cells, representing $60-70 \%$ of nonmalignant cells, whereas the proportion of neutrophils is usually less than $20 \%$ [175, 176]. While the proportion of B-lymphocytes is usually similar to that observed in the blood, the percentage of T-lymphocytes is uniformly higher than in the blood. However, the cytolytic function of these lymphocytes against autologous tumour cells was lower compared with blood lymphocytes. This is also observed for NK cell activity, suggesting that the pleural infiltrating lymphocytes (PILs) are in a state of immune suppression [177]. The ratio CD4+/CD8+ and the proportion of NK cells is usually similar to that observed in the blood [177]. In contrast, the expansion of these PILs, activated by IL-2, is much higher than that of peripheral blood lymphocytes (PBL) [178], and regression of MPE has been documented after intrapleural instillation of recombinant IL-2, IFN- $\alpha$ or IFN- $\gamma[130,131]$. It is crucial to know whether these regressions of MPE are mediated by specific (CTL) or aspecific (NK) antitumoral effector cells, or only by the sclerosing effect secondary to the release of inflammatory cytokines, such IL-8, by the mesothelial cells. Thus, it was clearly demonstrated that the control of MPE by instillation of OK-432 tetracycline, Corynebacterium parvum was not mediated by immune cells, but by the inflammatory response induced by the release from mesothelial cells of C5a, IL-8, IL- 6 or TNF, leading to pleural sclerosis $[177,179,180]$.

Although it is uncertain whether lymphocytes play a direct or indirect role in defence mechanisms against MPE, preliminary studies suggest that PILs represent a better source of LAK cells than the blood [181].

More recently, the pivotal role of chemotactic cytokines in the recruitment of mononuclear cells into the MPE has been documented. Platelet-derived growth factor (PDGF), a chemotactic agent and growth factor for mesenchymal cells was demonstrated to be secreted by adenocarcinoma cells. This could explain the strong stroma reaction observed in adenocarcinomal effusion. Furthermore, several chemotactic cytokines, such as macrophage chemotactic protein-1 (MCP-1) and IL-8 are produced both by mesothelial cells and tumour cells. Interestingly, ANTONy et al. [182] reported a strong correlation between the pleural level of MCP-1 and tumour invasion. Further understanding of mesothelial and tumour cell derived cytokines will be important in defining the mechanisms involved in the development of inflammatory processes into malignant pleural effusion, with the potential for novel therapeutic implications [182].

\section{Tumour antigen and active specific immunotherapy}

The concept of vaccination against cancer (active immunotherapy) is not recent and originates mainly from the success of vaccines in infectious diseases [183]. Unfortunately, despite the thousands of patients injected with various types of tumour vaccine during the last $50 \mathrm{yrs}$, only occasional clinical responses have been monitored [184]. The most important requisite for any conventional vaccine approach depends on the ability to identify specific antigens associated with neoplasia, and to elicit an appropriate protective host immune response to those antigens [185]. The strongest evidence for the existence of such antigens comes from the study of transplanted tumours in inbred animals. Thus, some of these tumours express antigens that elicit T-cell-mediated immune rejection responses in syngeneic host. These antigens, called transplanted specific tumour antigens (TSTAs) can either be specific for individual tumours (usually tumours induced by chemical or physical carcinogen) or common to a class of tumours (virus-induced tumours) [183-186].

In human LC, early studies focused on boosting immune response against putative tumour antigens with adjuvants, such as bacille Calmette-Guérin (BCG), Corynebacterium parvum and levamisole, each known to stimulate either cellular and/or humoral immune response. All of these trials are classified as "active nonspecific immunotherapy". The most commonly tested adjuvant was BCG, which was administered by various routes (intrapleural, intratumoral, interdermal or by aerosol) [187-190]. It is difficult to compare all these trials, owing to differences in strain, viability and concentration 
dose, as well as to the heterogeneity of population, stage of disease or time of therapy. However, two recent important randomized studies failed to show an additional survival benefit as compared to conventional treatment alone. By contrast, an increase of BCG-related empyemas was reported [191, 192]. Immunostimulants, such as Corynebacterium parvum and levamisole, have also failed to alter survival in lung cancer [191].

As opposed to passive immunization, "active specific immunotherapy" involves immune stimulation with tumour vaccines containing irradiated autologous or allogeneic tumour cells obtained from the tumour specimens. These tumour vaccines have been administered through different routes, such as intradermal, intralesional, intralymphatic or subcutaneous injection, and were occasionally combined with adjuvant products, such as BCG, Freund's complete adjuvant, or lytic virus. Rare positive results have been monitored in melanoma, carcinoma of the colon and superficial bladder cancer [184]. For lung tumours, despite several studies, no clear benefit has been reported so far [190, 193-195]. Moreover, all trials have shared two characteristic features: the therapeutic effect was not observed or, when observed, could not be confirmed independently; and no information was provided regarding the presence of tumour antigens in the vaccine.

We suggest that part of the failure in tumour vaccine immunotherapy has been due to the previous impossibility of matching immunogens to patients. Indeed, even when autologous tumour cells were used, there was no way to ascertain that a tumour antigen was expressed by these cells. The recent identification of TRAs and their encoding genes should shed new light on active specific immunotherapy in cancer patients [196]. It is now obvious that patients have to be selected for antitumour antigen immunization on the basis of the expression of the relevant antigen(s) by their tumour. Thus, eligibility criteria should include analysis of expression by the tumour of the gene encoding defined antigens. This can easily be performed by reverse transcription polymerase chain reaction (RT-PCR) on a small tumour sample correctly frozen and preserved.

The patient must also be typed for human leucocyte antigen (HLA). Thus, one should know whether a tumour expresses a peptide-HLA combination corresponding to known tumour antigen recognized by CTL. The number of NSCLC patients eligible for immunotherapy with one of the tumour antigens identified so far can be determined according to the percentage of tumour expressing the gene encoding defined antigens and the frequency of the given HLA class I molecule expression. At present, $49 \%$ of NCSLC patients could be included in immunotherapy trials with a tumour rejection antigen (table 3). Antigenic peptides derived from mutations in p53 and K-ras genes or overexpression of Her2-neu genes should represent additional antigens.

Once the patient becomes eligible, a mode of immunization must be chosen. To immunize against defined antigens recognized by T-cells, there is a vast array of different modalities, but at present it is not known which will be optimal in cancer patients. A first possibility is inoculation with peptide or purified protein. The ability of peptides to prime CD8+ T-cells in vivo has been demonstrated for viral antigens and rodent tumour
Table 3. - Percentage of non-small cell lung cancer (NSCLC) expressing antigens encoded by MAGE, BAGE or GAGE genes ( $\mathrm{n}=104$ patients)

\begin{tabular}{|c|c|c|c|c|c|c|}
\hline \multirow{2}{*}{$\begin{array}{l}\text { NSCLC } \\
\text { expressing } \\
\text { MAGE-B }\end{array}$} & & \multicolumn{5}{|c|}{ HLA Haplotype } \\
\hline & GE-GAGE \% & $\begin{array}{c}\text { A1 } \\
(26 \%)\end{array}$ & $\begin{array}{c}\text { A2 } \\
(49 \%) \\
\end{array}$ & $\begin{array}{c}\text { B44 } \\
(22 \%) \\
\end{array}$ & $\begin{array}{c}\text { CW16 } \\
(8 \%)\end{array}$ & $\begin{array}{l}\text { CW6 } \\
(16 \%) \\
\end{array}$ \\
\hline MAGE-1 & 45 & $12 *$ & & & $4 *$ & \\
\hline MAGE-2 & 49 & $13^{*}$ & $24 *$ & $11^{*}$ & & \\
\hline MAGE-3 & 49 & & & & $4^{*}$ & \\
\hline MAGE-6 & 52 & & & & & \\
\hline BAGE & 5 & & & & & \\
\hline GAGE & 19 & & & & & \\
\hline BAGE & 5 & & & & & \\
\hline BAGE & 5 & & & & & \\
\hline GAGE & 19 & & & & & $3 *$ \\
\hline
\end{tabular}

Values in parenthesis are the human leucocyte antigen (HLA) frequency for Caucasians. *: values are the percentage of patients with a tumour expressing a tumour antigen (TA) encoded by MAGE, BAGE, for each HLA haplotype. In total, $71 \%$ of NSCLC patients could be eligible for vaccination with one of these TAs. However, some NSCLC tumous express more than one TA. Therefore, in practice only $49 \%$ of NSCLC patients are eligible for vaccination.

antigens [197-199]. The success of this approach may depend on the adjuvant formulations. However, tumour regression responses in melanoma patients treated with a peptide encoded by gene $M A G E-3$ have recently been recorded [200]. Irradiated allogenic cells expressing the relevant antigen represent another possibility, but they will also induce an allogenic response preventing effective immunization against tumour antigen. If this approach is feasible, it may be possible to build cells expressing only the relevant HLA class I molecules. To improve the immunogenecity of these cells, one could engineer them to produce cytokines that play a role in the development of a CTL response, such as IL-2, IL-6 or IL12 , IFN- $\gamma$, or GM-CSF.

Transfecting the gene of the co-stimulatory molecule B7 may also prove very useful [201-204]. Another mode of immunization is the use of autologous specialized antigen-presenting cells, such as macrophages or dendritic cells, that can be isolated from the blood, pulsed in vitro with proteins or peptides, and inoculated back into the patient [205-207]. Recombinant viruses (adenovirus, vaccinia, retrovirus) or bacteria (BCG, Salmonella) carrying a gene coding for antigenic peptides can also be tested as immunogens. All these immunogens have to be tested and evaluated in prospective clinical studies to determine the best. The evaluation of immunization can be made by clinical observation showing the regression of tumour or prolonged disease-free survival if the vaccine is given as adjuvant therapy. It will also be very important to evaluate whether immunization results in increased production of CTL precursors [208].

To summarize, the main task is to demonstrate that effective immunogens can be derived with the available tumour rejection antigens. Furthermore, several drawbacks may limit the efficacy of immunization: the heterogeneity of tumour cells, with the possible presence of tumour cells lacking the expression of antigen. Unfortunately, this heterogeneity cannot be evaluated by RT-PCR. It could be tested by immunochemical staining or in situ hybridization but, at this time, no appropriate antibodies are available. However, if immunity 
can be raised against different tumour antigens, the loss of one of them would not necessarily result in tumour escape. Another problem is the loss of a molecule involved in the presentation pathway of the antigenic peptide, such as HLA class I, $\beta_{2}$-microglobulin, or transporters of antigenic peptides (TAP) protein [209-211]. Perhaps such HLA-negative cells could still be eliminated by NK cells, which appear to display specificity for cells having lost expression of HLA class molecules, supporting the concept of combined immunological pathways to eradicate the tumour efficiently [212].

In conclusion, despite improved knowledge of the mechanisms underlying the immune network, the role of immunology in cancer remains uncertain. Different defects have been reported to be associated with cancer. These include impaired cytotoxic activity both of macrophages and lymphocytes, potentially contributing to an inadequate immunosurveillance against cancer cells. However, the immune status is likely to vary from one individual to another and from one type of tumour compared to another. Moreover, it is likely that genetic and environmental factors are more important than the immune status in cancer patients. Therefore, better screening is probably required to define patients who would best benefit from treatment with agents stimulating their antitumoral immunity.

For example, some patients or tumours might respond to macrophage-stimulating agents while others could require lymphocyte activation. Furthermore, the majority of stimuli used so far, both in vitro and in clinical trials, trigger a variety of cell function. Some of these functions have demonstrated an increase of the antitumoral defence but others clearly diminish the tumoricidal activity. The regulation of the balance between these cell functions is likely to be critical for the outcome of the immune response. Molecular biology should lead to a better knowledge of intracellular pathways of activation, and hopefully provide new therapeutic agents with more specific targets.

In conclusion, considering the poor prognosis of patients with inoperable lung cancer, new therapeutic strategies need to be developed. In this regard, a better understanding of the immune mechanisms involved in cancer could provide efficacious alternative treatment, either alone or as adjuvant therapy.

Acknowledgements: The authors are grateful to I. Verbois and L. Collin for their careful secretarial assistance. The expertise of M-B. Jacqmain in the design and preparation of figures is also acknowledged.

\section{References}

1. Stjernward J, Stanley K. Lung cancer: a worldwide health problem. Lung Cancer 1988; 4: 11-12.

2. Thatcher N. Haematopoietic growth factors and lung cancer treatment. Thorax 1992; 47: 119-126.

3. Cortese DA, Edell ES. Role of phototherapy, laser therapy, brachytherapy, and prosthetic stents in the management of lung cancer. Clin Chest Med 1993; 14: 149-159.

4. Ruckdeschel JC, Codis SD, Stranahan A, McKneally MF. Postoperative empyema improves survival in lung cancer. N Engl J Med 1972; 287: 1013-1017.
5. Burnet FM. Cancer, a biological approach. $\mathrm{Br}$ Med $J$ 1957; 1: 844-852.

6. Sulitzeanu D. Immunosuppressive factors in human cancer. Adv Cancer Res 1993; 60: 247-267.

7. Holmes EK. The immunotherapy of lung cancer. Livingston RB, ed. Lung Cancer 1981; 1: 51-61.

8. Dillman RO, Koziol JA, Zavanelli MI, et al. Immunoincompetence in cancer patients. Cancer 1984; 53: 1481-1491.

9. Nakaruma H, Ishiguro K, Mori T. Different immune functions of peripheral blood, regional lymph node, and tumor-infiltrating lymphocytes in lung cancer. Cancer 1988; 62: 2489-2497.

10. Masumo T, Ikeda T, Yoka S, et al. Immunoregulatory T-lymphocyte functions in patients with small cell lung cancer. Cancer Res 1986; 46: 4195-4199.

11. Wei YQ, Hang ZB. In situ observation of lymphocytetumor interaction in human lung carcinoma. Immunol Invest 1989; 18: 1095-1105.

12. Ginns LO, De Hoyos A, Brown MC, Gaumon GR. Elevated concentration of soluble interleukin-2 receptors in serum of smokers and patients with lung cancer. Am Rev Respir Dis 1990; 142: 398-402.

13. Vanky F, Klein E, Willems J, et al. Lysis of autologous tumor cells by blood lymphocytes tested at time of surgery. Cancer Immunol Immunother 1986; 21: 69-76.

14. Uchida A, Yoshitaka K, Norihiko O, et al. Prediction of postoperative clinical course by autologous tumor killing activity in lung cancer patients. $J$ Natl Cancer Inst 1990; 82: 1697-1701.

15. Harris DT, Mastrangelo MJ. Serotherapy of cancer. Semin Oncol 1989; 16: 180-198.

16. Winter SF, Minna JD, Johnson BE, Takahashi T, Gazdar AF, Carbone DP. Development of antibodies against p53 in lung cancer patients appears to be dependent on the type of p53 mutation. Cancer Res 1992; 52: 4168-4174.

17. Drlicek M, Grisold W, Liszka U. Correlation of circulating antineuronal antibodies (CANA) with paraneoplastic syndromes in lung cancer. Lung Cancer 1993; 8: 245-258.

18. Winter SF, Sekido Y, Minna JD, et al. Antibodies against autologous tumor cell proteins in patients with small cell lung cancer: association with improved survival. $J$ Natl Cancer Inst 1993; 85: 2012-2018.

19. Kohler G, Milstein C. Continuous cultures of fused cells secreting antibody of predefined specificity. Nature 1975 ; 256: 495-497.

20. Souhami RL, Beverley PCL, Bobrow LG. Antigens of small lung cancer. Lancet 1987; ii: 325-326.

21. Souhami RL, Beverley PCL, Bobrow LG, Lederman JA. Antigens of lung cancer: results of the second international workshop on lung cancer antigens. J Natl Cancer Inst 1991; 83: 609-612.

22. Stahel RA, Gilks WR, Schenker T. Antigens of lung cancer: results of the third international workshop on lung tumor and differentiation antigens. J Natl Cancer Inst 1994; 86: 669-672.

23. Souhami RL. The antigens of lung cancer. Thorax 1992; 47: 53-56.

24. Patel K, Moore SE, Dickson G, et al. Neural cell adhesion molecule (NCAM) is the antigen recognized by monoclonal antibodies of similar specificity in small cell lung carcinoma and neuroblastoma. Int J Cancer 1989; 44: 573-578.

25. Pujol JL, Simony J, Demoly P, et al. Neural cell adhesion molecule and prognosis of surgically resected lung cancer. Am Rev Respir Dis 1993; 148: 1071-1075.

26. Stahel RA. Biologicals in the therapy of lung cancer. Lung Cancer 1991; 7: 123-130.

27. Stein R, Goldenberg DM. Prospects for the management of non-small cell carcinoma of the lung with monoclonal antibodies. Chest 1991; 99: 1466-1476. 
28. Linnoila RI, Mulshine JL, Steinberg SM, et al. Neuroendocrine differentiation in endocrine and neuroendocrine lung carcinomas. Am J Clin Pathol 1988; 90: 641-652.

29. Sheppard MN. Neuroendocrine differentiation in lung tumors. Thorax 1991; 46: 843-850.

30. Graziona SL. The use of neuroendocrine immunoperoxidase markers to predict chemotherapy response in patients with non-small cell lung cancer. J Clin Oncol 1989; 7: 1398-1406.

31. Berendsen HH. Clinical characterization of non-small cell lung cancer tumors showing neuroendocrine differentiation features. J Clin Oncol 1989; 7: 1614-1620.

32. Tockman MS, Gupta PK, Myers JD, et al. Sensitive and specific monoclonal antibody recognition of human lung cancer antigen on preserved sputum cells: a new approach to early lung cancer detection. J Clin Oncol 1988; 6: 1685-1693.

33. Zsabo E, Birrer MJ, Mulshine JL. Early detection of lung cancer. Semin Oncol 1993; 20: 374-382.

34. Mao L, Hruban RH, Boyle JO, Tockman M, Sidransky D. Detection of oncogene mutations in sputum precedes diagnosis of lung cancer. Cancer Res 1994; 54: 1634-1637.

35. Stahel RA, Marbry M, Skarin AT, et al. Detection of bone marrow metastases in small cell lung cancer by monoclonal antibody. J Clin Oncol 1985; 3: 455-461.

36. Canon JL, Humblet Y, Lebacq-Verheyden AM, et al. Immunodetection of small cell lung cancer metastases in bone marrow using three monoclonal antibodies. Eur J Cancer Clin Oncol 1988; 24: 147-150.

37. Leonard RCF, Duncan LW, Hay FG. Immunocytological detection of residual marrow disease at clinical remission predicts metastatic relapse in small cell lung cancer. Cancer Res 1990; 50: 6545-6548.

38. Mulshine JL, Cuttitta F, Minna JD. Lung cancer markers as detected by monoclonal antibodies. In: Sell S, Reisje RA, eds. Monoclonal Antibodies in Cancer. Clifton, NJ, USA. The Humana Press, Chapter 10. 1985; pp. 229-246.

39. Kramer EL, Larson SM. Tumor targeting with radiolabelled antibody for diagnosis and therapy. Human Cancer Immunology II. Immunol Allergy Clin N Am 1991; 11.2: 301-339.

40. Friedman S, Sullivan K, Salk D, et al. Staging nonsmall cell carcinoma of the lung using technetium- $99 \mathrm{~m}-$ labelled monoclonal antibodies. Hematol Oncol Clin N Am 1990; 4 (6): 1069-1078.

41. Buccheri G, Biggi A, Ferrigno D, et al. Imaging lung cancer by scintigraphy with indium-111-labelled $\mathrm{F}(\mathrm{ab})$ fragments of the anticarcinoembryonic antigen monoclonal antibody FO23C5. Cancer 1992; 70: 749-759.

42. Divgi CR, Welt S, Kris M, et al. Phase I and imaging trial of indium-111-labelled anti-epidermal growth factor receptor monoclonal antibody 225 in patients with squamous cell lung carcinoma. J Natl Cancer Inst 1991; 83: $97-104$

43. Buccheri G, Biggi A, Ferrigno D, et al. Anti-CEA immunoscintigraphy might be more useful than computed tomography in the preoperative thoracic evaluation of lung cancer. Chest 1993; 104: 734-742.

44. Boilleau G, Pujol JL, Ychou M, et al. Detection of lymph node metastases in lung cancer: comparison of ${ }^{131} \mathrm{I}$-antiCEA-anti-CA19-9 immunoscintigraphy versus computed tomography. Lung Cancer 1994; 11: 209-219.

45. Humblet Y, Feyens AM, Sekhavat M, et al. Immunological and pharmacological removal of small cell lung cancer cells from bone marrow autografts. Cancer Res 1989; 49: 5058-5061.

46. Bernard J, Bettan-Renaud L, Gavoille A, et al. In vitro chemical eradication of small cell lung cancer: application in autologous bone marrow transplantation. Eur J Cancer Clin Oncol 1988; 24: 1561-1566.
47. Stahel RA, Lacroix H, Sculier JP, et al. Phase I/II study of monoclonal antibody against Lewis $\mathrm{Y}$ hapten in relapsed small cell lung cancer. Ann Oncol 1992; 3: 319-320.

48. Foon KA. Biological response modifiers: the new immunotherapy. Cancer Res 1989; 49: 1621-1639.

49. Mach JP, Pelegrin A, Buchegger F. Imaging and therapy with MoAb in nonhematopoietic tumors. Curr Opin Immunol 1991; 3: 685-693.

50. Smith A, Waibel R, Stahel RA. Selective immunotherapy of small cell cancer xenografts using ${ }^{131}$ I-labelled SWA11 antibody. Br J Cancer 1991; 64: 263-266.

51. Wawrynczak EJ, Derbyshire EJ, Henry RV, et al. Selective cytotoxic effects of a ricin A chain immunotoxin made with the monoclonal antibody SWA11 recognizing a human small cell lung cancer antigen. Br J Cancer 1990; 62: 410-414.

52. Wawrzynczak EJ, Derbyshire EJ, Henry RV, et al. Cytotoxic activity of ricin A chain immunotoxins recognizing cluster 1, w4 and 5A antigens associated with human small cell lung cancer. Br J Cancer 1991; 63 (Suppl. XIV): 71-73.

53. Lynch TJ Jr. Immunotoxin therapy of small cell lung cancer: N901-blocked ricin for relapsed small cell lung cancer. Chest 1993; 103: 436S-439S.

54. Bleehen NM, Rabbitts PH, Reeve JG. Report on the 3rd IASLC lung tumor biology workshop held at Robinson College, Cambridge, 6-9 August 1990. Lung Cancer 1991; 7: 171-178.

55. Bumol TF, Deherdt SV, Zimmerman DL, Apelgren LD. Monoclonal antibody-oncolytic drug conjugates for sitedirected therapy of human adenocarcinomas. Proc Am Assoc Cancer Res 1989; 30: 647-648.

56. Lang RA, Burgess AW. Autocrine growth factors and tumorigenic transformation. Immunol Today 1990; 11: 244-249.

57. Woll PJ, Rozengurt E. Therapeutic implications of growth factors in small cell lung cancer. Lung Cancer 1989; 5: 169-177.

58. Woll PJ. Growth factors and lung cancer. Thorax 1991; 46: 924-929.

59. Cuttitta F, Carney DN, Mulshine J, et al. Bombesin-like peptides can function as autocrine growth factors in human small cell lung cancer. Nature 1985; 316: 823 826.

60. Avis IL, Kovacs TO, Kasprzyk PG, et al. Preclinical evaluation of an anti-autocrine growth factor monoclonal antibody for treatment of patients with small cell lung cancer. J Natl Cancer Inst 1991; 83: 1470-1476.

61. Mulshine JL, Shuke H, Daghighian F, et al. The correct dose: pharmacologically guided end point for antigrowth factor therapy. Cancer Res 1992; 52: 2743s-2746s.

62. Masui H, Kamrath H, Apell G, et al. Cytotoxicity against human tumor cells mediated by the conjugate of antiepidermal growth factor receptor monoclonal antibody to recombinant ricin a chain. Cancer Res 1989; 49: 3482-3488.

63. Woll PJ, Rozengurt E. A neuropeptide antagonist that inhibits the growth of small cell lung cancer in vitro. Cancer Res 1990; 50: 3968-3973.

64. Sethi T, Langdon S, Smyth J, Rozengurt E. Growth of small cell lung cancer cells: stimulation by multiple neuropeptides and inhibition by broad spectrum antagonists in vitro and in vivo. Cancer Res 1992; 52: 2737s2742s.

65. Langdon S, Sethi T, Ritchie A, Muir M, Smyth J, Rozengurt E. Broad spectrum neuropeptide antagonists inhibit the growth of small cell lung cancer in vivo. Cancer Res 1992; 52: 4554-4557.

66. Bepler G, Carney DN, Gazdar AF, Minna JD. In vitro growth inhibition of human small cell lung cancer by physalaemin. Cancer Res 1987; 47: 2371-2375. 
67. Reubi JC, Waser B, Sheppard M, Macaulay B. Somatostatin receptors are present in small cell but not in nonsmall cell primary lung carcinomas: relationship to EGF-receptors. Int J Cancer 1990; 45: 269-274.

68. Bogden AE, Taylor JE, Moreau JP, et al. Response of human lung tumor xenografts to treatment with a somatostatin analogue (somatuline). Cancer Res 1990; 50: 4360-4365.

69. Kvols LK, Reubi JC, Horisberger U, Moertel CG, Rubin J, Charboneau JW. The presence of somatostatin receptors in malignant neuroendocrine tumor tissue predicts responsiveness to octerotide. Yale J Biol Med 1992; 65: 505-518.

70. Anthony L, Johnson D, Hande K, et al. Somatostatin analogue phase I trials in neuroendocrine neoplasms. Acta Oncol 1993; 32 (2): 217-223.

71. Mukhopadhyay T, Tainsky M, Cavender AC, Roth JA. Specific inhibition of $K$-ras expression and tumorigenicity of lung cancer cells by antisense RNA. Cancer Res 1991; 51: $1744-1748$

72. O'Connell MJ, Chen ZJ, Yang H, et al. Active specific immunotherapy with anti-idiotypic antibodies in patients with solid tumors. Semin Surg Oncol 1989; 5: 441-447.

73. Herlyn D, Wettendorff M, Schmoll E, et al. Anti-idiotype immunization of cancer patients: modulation of the immune response. Proc Natl Acad Sci (USA) 1987; 84: 8055-8059.

74. Mittelman A, Chen ZJ, Yang H, Wong GY, Ferrone S. Human high molecular weight melanoma-associated antigen (HMW-MAA) mimicry by mouse anti-idiotypic monoclonal antibody MK2-23: induction of humoral anti-HMW-MAA immunity and prolongation of survival in patients with stage IV melanoma. Proc Natl Acad Sci (USA) 1992; 89: 466-470.

75. Zwicky C, Stahel RA, Jaksche H, et al. Polyclonal antiidiotypic antibodies mimicking the small cell lung carcinoma antigen cluster-5A interact with a panel of antibodies and induce specific immune response in animals. Br J Cancer 1991; 63: 67-70.

76. Barth A, Waibel R, Stahel RA. Monoclonal anti-idiotypic antibody mimicking a tumor-associated sialoglycoprotein antigen induces humoral immune response against human small cell lung carcinoma. Int J Cancer 1989; 43: 896-900.

77. Lehmann HP, Zwicky C, Waibel R, Stahel RA. Tumor antigen-specific humoral immune response of animals to anti-idiotypic antibodies and comparative serological analysis of patients with small cell lung carcinoma. Int J Cancer 1992; 50: 86-92.

78. Kuzel TM, Rosen ST. Antibodies in the treatment of human cancer. Curr Opin Oncol 1994; 6: 622-626.

79. Stötter H, Lotze MT. Cytolytic effector cells against human tumors: distinguishing phenotype and function. Cancer Cells 1990; 2: 44-55.

80. Whiteside TL, Herberman RB. Human natural killer cells in health and disease: biology and therapeutical potential. Clin Immunother 1994; 1: 56-66.

81. Sibbitt WL, Bankhurst AD, Jumonville AJ, Saiki JH, Saiers JH, Doberneck RC. Defects in natural killer cell activity and interferon response in human lung carcinoma and malignant melanoma. Cancer Res 1984; 44: 852-856.

82. Ching-Chi L, Yuh-Chi K, Wen-Chu H, Ching-Yuang L. Natural killer cell activity in lung cancer patients. Chest 1987; 92: 1022-1024.

83. Weissler JC, Nicod LP, Lipscomb MF, Toews GB. Natural killer cell function in human lung is compartmentalized. Am Rev Respir Dis 1987; 135: 941-949.

84. Pitchenik AE, Guffee J, Stein-Streilein J. Lung natural killer and Interleukin-2 activity in lung cancer. Am Rev Respir Dis 1987; 136: 1327-1332.
85. Cook JL. Natural killer cell activity associated with human neoplasms. Am Rev Respir Dis 1987; 136: 1323-1324.

86. Grimm EA, Mazumder A, Zhang HZ, Rosenberg SA. Lymphokine-activated killer cell phenomenon: lysis of natural killer-resistant fresh solid tumor cells by interleukin-2-activated autologous human peripheral blood lymphocytes. J Exp Med 1982; 155: 1823-1841.

87. Robinson BWS, Morstyn G. Natural killer (NK)-resistant human lung cancer cells are lysed by recombinant interleukin-2 activated NK cells. Cell Immunol 1987; 106: 215-222.

88. Lagadec PF, Saraya KA, Balkwill FR. Human small cell lung cancer cells are cytokine-resistant but NK/LAKsensitive. Int J Cancer 1991; 48: 311-317.

89. Kimura H, Yamaguchi Y, Fujisawa T. Cytotoxicity of autologous and allogeneic lymphocytes against cultured human lung cancer cells: optimal conditions for the production of cytotoxic lymphocytes. Gann 1984; 75: 1006-1016.

90. Fujita J, Saijo N, Sasaki Y, et al. Detection of cytotoxicity of freshly obtained lymphocytes and of lymphocytes activated with recombinant interleukin-2 (rIL-2) against lung cancer cell lines by human tumour clonogenic assay (HTCA). Eur J Cancer Clin Oncol 1986; 22: 445-450.

91. Yano T, Yasumoto K, Nomoto K. Generation and expansion of lymphokine-activated killer cells from lymph node lymphocytes in human lung cancer. Eur J Cancer Clin Oncol 1989; 25: 201-208.

92. Boon T, Cerottini JC, Van den Eynde B, van der Bruggen $\mathrm{P}$, Van Pel A. Tumor antigens recognized by T-lymphocytes. Annu Rev Immunol 1994; 12: 337-365.

93. Anichini A, Fossati G, Parmiani G. Clonal analysis of the cytolytic T-cell response to human tumors. Immunol Today 1987; 8: 385-389.

94. Hérin M, Lemoine C, Weynants P, et al. Production of stable cytolytic T-cell clones directed against autologous human melanoma. Int J Cancer 1987; 39: 390-396.

95. Hainaut P, Weynants P, Coulie PG, Boone T. Antitumor T-lymphocyte responses. Immunol Allergy Clin N Am 1990; 10: 639-662.

96. Boon T, Coulie P, Marchand M, Weynants P, Wölfel $\mathrm{T}$, Brichard V. Genes coding for tumor rejection antigens: perspectives for specific immunotherapy. In: De Vita V, ed. Important Advances in Oncology. Philadelphia, JB Lippincott Company, 1994; pp. 53-69.

97. Van den Eynde B, Brichard VG. New tumor antigens recognized by T-cells. Curr Opinion Immunol 1995; 7 : 674-681.

98. van der Bruggen $\mathrm{P}$, Traversari $\mathrm{C}$, Chomez $\mathrm{P}$, et al. A gene encoding an antigen recognized by cytolytic $\mathrm{T}$ lymphocytes on a human melanoma. Science 1991; 254: 1643-1647.

99. Traversari $\mathrm{C}$, van der Bruggen $\mathrm{P}$, Luescher IF, et al. A nonapeptide encoded by human gene MAGE-l is recognized on HLA-A1 by cytolytic T-lymphocytes directed against tumor antigen MZ2-E. J Exp Med 1992; 176: 1453-1457.

100. Gaugler B, Van den Eynde B, van der Bruggen P, et al. Human gene MAGE-3 codes for an antigen recognized on a melanoma by autologous cytolytic T-lymphocytes. J Exp Med 1994; 179: 921-930.

101. Van den Eynde B, Peeters O, De Backer O, Gaugler B, Lucas S, Boon T. A new family of genes coding for an antigen recognized by autologous cytolytic T-lymphocytes on a human melanoma. $J$ Exp Med 1995; 182: 689-698.

102. Boël P, Wildmann C, Sensi ML, et al. BAGE, a new gene encoding an antigen recognized on human melanomas by cytolytic T-lymphocytes. Immunity 1995; 2: $167-175$. 
103. Weynants P, Lethé B, Brasseur F, Marchand M, Boon T. Expression of MAGE genes by non-small cell lung carcinomas. Int J Cancer 1994; 56: 826-829.

104. Brichard V, Van Pel A, Wölfel T, et al. The tyrosinase gene codes for an antigen recognized by autologous cytolytic T-lymphocytes on HLA-A2 melanomas. J Exp Med 1993; 178: 489-495.

105. Coulie P, Brichard V, Van Pel A, et al. A new gene coding for a differentiation antigen recognized by autologous cytolytic T-lymphocytes on HLA-A2 melanomas. J Exp Med 1994; 180: 35-42.

106. Kawakami Y, Eliyahu S, Delgado $\mathrm{CH}$, et al. Cloning of the gene coding for a shared human melanoma antigen recognized by autologous T-cells infiltrating into tumor. Proc Natl Acad Sci USA 1994; 91: 3515-3519.

107. Kwon BS, Chintamaneni C, Kozak CA, et al. A melanocyte-specific gene, Pmel 17, maps near the silver coat color locus on mouse chromosome 10 and is a syntenic region on human chromosome 12. Proc Natl Acad Sci USA 1991; 88: 9228-9232.

108. Bakker ABH, Schreurs MWJ, de Boer AJ, et al. Melanocyte lineage-specific antigen gp100 is recognized by melanoma-derived tumor-infiltrating lymphocytes. $J$ Exp Med 1994; 179: 1005-1009.

109. Coulie P, Lehmann F, Lethé B, et al. A mutated intron sequence codes for an antigenic peptide recognized by cytolytic T-lymphocytes on a human melanoma. Proc Natl Acad Sci USA 1995; 92: 7976-7980.

110. Wölfel T, Hauer M, Schneider J, et al. A p16 $6^{\mathrm{INK} 4 \mathrm{a}}$-insensitive CDK4 mutant targeted by cytolytic T-lymphocytes in a human melanoma. Science 1995; 269: 1281-1284.

111. Brändle D, Brasseur F, Weynants $\mathrm{P}$, Boon T, Van den Eynde B. A mutated HLA-A2 molecule recognized by autologous cytotoxic T-lymphocytes on a human renal cell carcinoma. J Exp Med 1996; 183: 2501-2508.

112. Yoshino I, Yano T, Yoshikai Y, et al. Oligoclonal Tlymphocytes infiltrating human lung cancer tissues. Int J Cancer 1991; 47: 654-658.

113. Melioli G, Ratto G, Guastella M, et al. Isolation and in vitro expansion of lymphocytes infiltrating non-small cell lung carcinoma: functional and molecular characterisation for their use in adoptive immunotherapy. Eur $J$ Cancer 1994; 30A (1): 97-102.

114. Meta M, Ponte M, Guastella M, et al. Detection of oligoclonal T-lymphocytes in lymph nodes draining from advanced non-small cell lung cancer. Cancer Immunol Immunother 1995; 40: 235-240.

115. Vose BM, Bonnard GD. Specific cytotoxicity against autologous tumour and proliferative responses of human lymphocytes grown in interleukin-2. Int J Cancer 1982; 29: 33-39.

116. Slingluff CL, Cox AL, Stover JM, Moore MM, Hunt DF, Engelhard VH. Cytotoxic T-lymphocyte response to autologous human squamous cell cancer of the lung: epitope reconstitution with peptides extracted from HLAAw68. Cancer Res 1994; 54: 2731-2737.

117. Nakao M, Yamana H, Imai Y, et al. HLA A2601-restricted CTLs recognize a peptide antigen expressed on squamous cell carcinoma. Cancer Res 1995; 55: 4248-4252.

118. Weynants P, Marchand M, Thonnard J, Delos M, Boon T, Coulie P. Production of cytolytic T-cell clones directed against autologous small cell and non-small cell, lung cancer cell lines. (Abstract). Lung Cancer 1997; (in press).

119. Yoshino I, Goedegebuure PS, Peoples GE, et al. HER2/ neu-derived peptides are shared antigens among human non-small cell lung cancer and ovarian cancer. Cancer Res 1994; 54: 3387-3390.

120. Rosenberg SA, Lotze MT, Yang JC, et al. Experience with the use of high-dose interleukin-2 in the treatment of 652 cancer patients. Ann Surg 1989; 210: 474-483.
121. Bernstein ZP, Goldrosen MH, Vaickus L, et al. Interleukin-2 with ex-vivo activated killer cells: therapy of advanced non-small cell lung cancer. J Immunother 1991; 10 (5): 383-387.

122. Yang SC, Owen-Schaub L, Mendiguren-Rodriguez A, Grimm EA, Hong WK, Roth JA. Combination immunotherapy for non-small cell lung cancer: results with interleukin-2 and tumor necrosis factor- $\alpha$. J Thorac Cardiovasc Surg 1990; 99: 8-13.

123. Jansen RLH, Slingerland R, Hoo Goey S, Franks CR, Bolhuis RLH, Stoter G. Interleukin-2 and interferon- $\alpha$ in the treatment of patients with advanced non-small cell lung cancer. J Immunother 1992; 12 (1): 70-73.

124. West WH, Tauer KW, Yannelli JR, et al. Constant-infusion recombinant interleukin-2 in adoptive immunotherapy of advanced cancer. $N$ Engl J Med 1987; 316: 898-905.

125. Ardizzoni A, Bonavia M, Viale M, et al. Biologic and clinical effects of continuous infusion interleukin-2 in patients with non-small cell lung cancer. Cancer 1994; 73: $1353-1360$.

126. Scudeletti M, Filaci G, Imro MA, et al. Immunotherapy with intralesional and systemic interleukin-2 of patients with non-small cell lung cancer. Cancer Immunol Immunother 1993; 37: 119-124.

127. Kradin RL, Lazarus DS, Dubinett SM, et al. Tumourinfiltrating lymphocytes and interleukin-2 in treatment of advanced cancer. Lancet 1989; i: 577-580.

128. Clamon G, Hemdon J, Perry MC, et al. Interleukin-2 activity in patients with extensive small cell lung cancer: a phase II trial of cancer and leukemia group B. $J$ Natl Cancer Inst 1993; 85 (4): 316-320.

129. Rosenberg SA, Packard BS, Aebersold PM, et al. Use of tumor-infiltrating lymphocytes and interleukin-2 in the immunotherapy of patients with metastatic melanoma: a preliminary report. $N$ Engl J Med 1988; 319 (25): 1676-1988.

130. Yasumoto K, Miyazaki K, Nagashima A, et al. Induction of lymphokine-activated killer cells by intrapleural instillations of recombinant interleukin-2 in patients with malignant pleurisy due to lung cancer. Cancer Res 1987; 47: 2184-2187.

131. Astoul Ph, Viallat JR, Laurent JC, Brandely M, Boutin C. Intrapleural recombinant IL-2 in passive immunotherapy for malignant pleural effusion. Chest 1993; 103: 209-213.

132. Parmiani G. An explanation of the variable clinical response to interleukin 2 and LAK cells. Immunol Today 1990; 11(4): 113-115.

133. Kimura H, Yamaguchi Y. Adjuvant immunotherapy with interleukin-2 and lymphokine-activated killer cells after noncurative resection of primary lung cancer. Lung Cancer 1995; 13: 31-44.

134. Ratto GB, Melioli G, Zino P, et al. Immunotherapy with the use of tumor-infiltrating lymphocytes and interleukin2 as adjuvant treatment in stage III non-small cell lung cancer: a pilot study. J Thorac Cardiovasc Surg 1995; 109: 1212-1217.

135. Olesen BK, Ernst P, Nissen MH, Hansen HH. Recombinant interferon- $\alpha(\mathrm{rIFN}-\alpha)$ therapy of small cell and squamous cell carcinoma of the lung: a phase II study. Eur J Cancer Clin Oncol 1987; 23 (7): 987-989.

136. van Zandwijk N, Jassem E, Dubbelmann R, Braat P, Rumke P. Aerosol application of interferon-alpha in the treatment of bronchoalveolar carcinoma. Eur J Cancer 1990; 26 (6): 738-740.

137. Wheeler RH, Herndon JE, Clamon GH, Green MR. A phase II study of recombinant $\beta$-interferon at maximum tolerated dose in patients with advanced non-small cell lung cancer: a cancer and leukemia group B study. $J$ Immunother 1994; 15: 212-216. 
138. Jassem J. Biological treatment of NSCLC: the need for conclusive studies. Chest 1996; 109 (5): 119S-124S.

139. Mattson K, Niiranen A, Pyrhönen S, et al. Natural interferon- $\alpha$ as maintenance therapy for small cell lung cancer. Eur J Cancer 1992; 28A (8/9): 1387-1391.

140. Jett JR, Maksymiuk AW, Su JQ, et al. Phase III trial of recombinant interferon gamma in complete responders with small-cell lung cancer. J Clin Oncol 1994; 12: 2321-2326.

141. Boutin C, Viallat JR, Van Zandwijk N, et al. Activity of intrapleural recombinant gamma-interferon in malignant mesothelioma. Cancer 1991; 67: 2033-2037.

142. Carmichael J, Fergusson RJ, Wolf CR, Balkwill FR, Smyth JF. Augmentation of cytotoxicity of chemotherapy by human $\alpha$-interferons in human non-small cell lung cancer xenografts. Cancer Res 1986; 46: 49164920.

143. Kajata V, Yap A. Combination of cisplatin and interferon- $\alpha 2 a$ (Roferon $\left.{ }^{\circledR}-A\right)$ in patients with non-small cell lung cancer (NSCLC): an open phase II multicentre study. Eur J Cancer 1995; 31A (1): 35-40.

144. Schiller JH, Storer B, Dreicer R, Rosenquist D, Frontiera M, Carbone PP. Randomized phase II-III trial of combination beta- and gamma-interferons and etoposide and cisplatin in inoperable non-small cell cancer of the lung. J Natl Cancer Inst 1989; 81: 1739-1743.

145. Ardizzoni A, Rosso R, Salvati F, et al. Combination chemotherapy and interferon $\alpha 2 b$ in the treatment of advanced non-small-cell lung cancer. Am J Clin Oncol 1991; 14 (2): 120-123.

146. Mantovani A, Botazzi B, Colotta F, et al. The origin and function of tumor-associated macrophages. Immunol Today 1992; 13: 265-270.

147. Mantovani A. Biology of disease. Tumor-associated macrophages in neoplastic progression: a paradigm for the in vivo function of chemokines. Lab Invest 1994; 71: 5-16.

148. Thomassen MJ, Wiedemann HP, Barna BP, et al. Induction of in vitro tumoricidal activity in alveolar macrophages and monocytes from patients with lung cancer. Cancer Res 1988; 48: 3949-3953.

149. Kuda T, Yasumoto K, Yano T, et al. Role of antitumor activity of alveolar macrophages in lung cancer patients. Cancer Res 1987; 47: 2199-2202.

150. Sone S, Utsugi T, Nii A, et al. Effects of human alveolar macrophages on the induction of lymphokine (IL2)-activated killer cells. J Immunology 1987; 139: 29-34.

151. Sibille Y, Reynolds HY. Macrophages and polymorphonuclear neutrophils in lung defense and injury: state of the art. Am Rev Respir Dis 1990; 141: 471-501.

152. Weissler JC, Lipscomb MF, Lem VM, et al. Tumor killing by human alveolar macrophages and blood monocytes. Am Rev Respir Dis 1986; 134: 532-537.

153. Drysdale BE, Agrawal S, Shin HS. Macrophages-mediated tumoricidal activity: mechanisms of activation and cytotoxicity. Prog Allergy 1988; 40: 111-161.

154. Siziopikou KP, Harris JE, Casey L, Nawas Y, Braun DP. Impaired tumoricidal function of alveolar macrophages from patients with non-small cell lung cancer. Cancer 1991; 68: 1035-1044.

155. Renoux M, Lemarie E, Renoux G. Interleukin-1 secretion by lipopolysaccharide-stimulated alveolar macrophages: relationships to cell numbers, influence of smoking habits. Respiration 1989; 55 (3): 158-168.

156. Marchandise FX, Mathieu B, Staquet $\mathrm{P}$, et al. Tumor necrosis factor- $\alpha$ release from cultured whole blood, blood mononuclear cells and bronchoalveolar lavage cells in normals and lung cancer patients (Abstract). Chest 1988; 94: 455

157. Cembrzynska-Nowak M, Inglot AD, Szklarz E, Albin M. Hyporesponsiveness of human alveolar leukocytes to interferon-alpha and interferon-gamma inducers. Immunobiology 1990; 181(1): 84-96.

158. Fidler IJ, Sone S, Fogler WE, et al. Eradication of spontaneous metastases and activation of alveolar macrophages by intravenous injection of liposomes containing muramyl dipeptide. Proc Natl Acad Sci USA 1981; 78: $1680-1684$.

159. Semeraro N, De Lucia O, Lattanzio A, et al. Procoagulant activity of human alveolar macrophages: different expression in patients with lung cancer. Int J Cancer 1986; 37 (4): 525-529.

160. Koch AE, Polverini PJ, Kunkel SL, et al. Interleukin-8 (IL-8) as a macrophage-derived mediator of angiogenesis. Science 1992; 141: 1279-1284.

161. Arenberg DA, Kunkel SL, Polverini PJ, Glass M, Burdick MD, Strieter RM. Inhibition of interleukin-8 reduces tumorigenesis of human non-small cell lung cancer in SCID mice. J Clin Invest 1996; 97: 2792-2802.

162. Leonard EJ, Yoshimura T. Neutrophil attractant/activation protein-1 (NAP-1 (interleukin-8)). Am J Respir Cell Mol Biol 1990; 2: 479-486.

163. Sibille Y, Marchandise FX. Pulmonary immune cells in health and disease: polymorphonuclear neutrophils. Eur Respir J 1993; 6: 1529-1543.

164. Musiani P, Allione A, Modica A, et al. Role of neutrophils and lymphocytes in inhibition of a mouse mammary adenocarcinoma engineered to release IL-2, IL-4, IL-7, IL-10, IFN- $\alpha$, IFN- $\gamma$ and TNF- $\alpha$. Lab Invest 1996; 74: $146-157$.

165. Albelda SM. Role of integrins and other cell adhesion molecules in tumor progression and metastasis. $L a b$ Invest 1993; 68: 4-17.

166. Stetler-Stevenson WG, Aznovoorian S, Liotta LA. Tumor cell interactions with the extracellular matrix during invasion and metastasis. Annu Rev Cell Biol 1993; 9: 541-573.

167. Clark EA, Brugge JS. Integrins and signal transduction pathways: the road taken. Science 1995; 268: 233-239.

168. Ledda MF, Adris S, Bravo AI, et al. Suppression of SPARC expression by antisense RNA abrogates the tumorigenecity of human melanoma cells. Nature Med 1997; 3: 171-176.

169. Sage EH. Terms of attachment: SPARC and tumorigenesis. Nature Med 1997; 3: 144-146.

170. Tallett A, Chilvers ER, Hannah S, et al. Inhibition of neuropeptide-stimulated tyrosine phosphorylation and tyrosine kinase activity stimulates apoptosis in small cell lung cancer cells. Cancer Res 1996; 56: 4255-4263.

171. Nishimura M, Machida K, Imaizumi M, et al. Tyrosine phosphorylation of $100-130 \mathrm{kDa}$ proteins in lung cancer correlates with poor prognosis. Br J Cancer 1996; 74: 780-787.

172. Melis M, Spatafora M, Melodia A, et al. ICAM-1 expression by lung cancer cell lines: effects of upregulation by cytokines on the interaction with LAK cells. Eur Respir J 1996; 9: 1831-1838.

173. Arase H, Arase N, Saito T. Fas-mediated cytotoxicity by freshly isolated natural killer cells. J Exp Med 1995; 181: 1235-1238.

174. Seino KI, Kayagaki N, Okumura K, Yagita H. Antitumor effect of locally produced CD95 ligand. Nature Med 1997; 3: 165-170.

175. Rossi GA. Cells of the pleural space. In: Crystal RG, West JB, et al., eds. The Lung: Scientific Foundations. New York, Raven Press Ltd, 1991.

176. Sahn SA. The pleura: state of the art. Am Rev Respir Dis 1988; 138: 184-234.

177. Rossi GA, Felletti R, Balbi B, et al. Symptomatic treatment of recurrent malignant pleural effusions with intrapleurally administered Corynebacterium parvum. Am Rev Respir Dis 1987; 135: 885-890. 
178. Guo Y, Xing Z. The cytotoxicity of malignant pleural effusion lymphocytes and LAK cells against autologous tumor cells. Chung Hua Chieh Ho Ho Hu Hsi Tsa Chih 1995; 18: 80-82.

179. Ching-Chi L, Chuan-Chuan L, Ching-Yuang L. Changes in cell population and tumor necrosis factor, interleukin6 , and interleukin-8 in malignant pleural effusions after treatment with intrapleural tetracycline. Am Rev Respir Dis 1993; 147: 1503-1506.

180. Kataoka M, Morishita R, Hiramatsu J, et al. OK-432 induces production of neutrophil chemotactic factors in malignant pleural effusion. Intern Med 1995; 34: 352-356.

181. Lissoni $\mathrm{P}$, Barni $\mathrm{S}$, Tancini $\mathrm{G}$, et al. Intracavitary therapy of neoplastic effusions with cytokines: comparison among interferon-alpha, -beta and interleukin-2. Support Care Cancer 1995; 3: 78-80.

182. Antony VB, Godbey SW, Kunkel SL, et al. Recruitment of inflammatory cells to the pleural space: chemotactic cytokines, IL-8, and monocyte chemotactic peptide1 in human pleural fluids. J Immunol 1993; 151: 7216-7223.

183. Morton DL. Active immunotherapy against cancer: present status. Semin Oncol 1986; 13: 180-185.

184. Livingston $\mathrm{Ph}$. Active specific immunotherapy in the treatment of patients with cancer. Immunol Allergy $N$ Am 1991; 11: 401-423.

185. Cole JS, Gruber J. Commentary: progress and prospects for human cancer vaccines. J Natl Cancer Inst 1991: 84: 18-23.

186. Boon Th. Tum ${ }^{-}$variants: immunogenic variants obtained by antigen treatment of tumour cells. Immunol Today 1985; 6: 307-311.

187. McKneally MF, Maver C, Kausel HW. Regional immunotherapy of lung cancer with intrapleural BCG. Lancet 1976; ii: $377-379$.

188. Mountain CF, Gail MH. Surgical adjuvant intrapleural BCG treatment for stage I non-small cell lung cancer. J Thorac Cardiovasc Surg 1981; 82 (5): 649-657.

189. Holmes EC, Ramming KP, Bein ME, Coulson WF, Callery CD. Intralesional BCG immunotherapy of pulmonary tumors. J Thorac Cardiovasc Surg 1979; 3: 362-368.

190. Fishbein GE. Immunotherapy of lung cancer. Semin Oncol 1993; 20 (4): 351-358.

191. Lung Cancer Study Group (LCSG). Immunostimulation with intrapleural BCG as adjuvant therapy in resected non-small cell lung cancer. Cancer 1986; 58: 2411-2416.

192. Matthay RA, Mahler DA, Beck GJ, et al. Intratumoral bacillus Calmette-Guérin immunotherapy prior to surgery for carcinoma of the lung: results of a prospective randomized trial. Cancer Res 1986; 46: 5963-5968.

193. Hollinshead A, Stewart HM, Takita H, Dalbow M, Concannon J. Adjuvant-specific active lung cancer immunotherapy trials. Cancer 1987; 60: 1249-1262.

194. Takita H, Hollinshead AC, Adler RH, et al. Adjuvantspecific active immunotherapy for resectable squamous cell lung carcinoma: a 5 year survival analysis. $J$ Surg Oncol 1991; 46: 9-14.

195. Price-Evans DA, Roberts HL, Hewitt S, Walsh D, Donohoe WTA, Lambourne A. A trial of adjuvant immunotherapy for bronchial carcinoma with irradiated autochthonous tumor cells. Int J Immunother 1987; 3: 293-305.

196. Coulie PG. Antigens recognized on human tumors by cytolytic T-lymphocytes: towards vaccination? Stem Cells 1995; 13 (4): 393-403.

197. Kast WM, Roux L, Curren J, et al. Protection against lethal Sendai virus infection by in vivo priming of virus-specific cytotoxic T-lymphocytes with a free synthetic peptide. Proc Natl Acad Sci USA 1991; 88: 2283-2287.

198. Schulz M, Zinkernagel RM, Hengartner H. Peptideinduced antiviral protection by cytotoxic T cells. Proc Natl Acad Sci USA 1991; 88: 991-993.

199. Mandelboim O, Vadai E, Fridkin M, et al. Regression of established murine carcinoma metastasis following vaccination with tumor-associated antigen peptides. Nature Med 1995; 1: 1179-1183.

200. Marchand M, Weynants P, Rankin E, et al. Tumor regression responses in melanoma patients treated with a peptide encoded by gene MAGE-3. Int J Cancer 1995; 63: 883-885.

201. Fearon ER, Pardoll DM, Itaya T, et al. Interleukin-2 production by tumor cells bypasses T-helper function in the generation of antitumor response. Cell 1990; 60: 397-403.

202. Golumbek PT, Lazenby AJ, Levitsky HI, et al. Treatment of established renal cancer by tumor cell engineered to secrete interleukin-4. Science 1991; 254: 713-716.

203. Watanabe Y, Kuribayashi K, Mitadabe S, et al. Exogenous expression of mouse interferon-gamma cDNA in mouse neuroblastoma $\mathrm{C} 1300$ cells results in reduced tumorigenicity by augmented antitumor immunity. Proc Natl Acad Sci USA 1989; 86: 9456-9460.

204. Townsend S, Allison JP. Tumor rejection after direct co-stimulation of CD8+ T-cells by B7-transfected melanoma cells. Science 1993; 259: 368-370.

205. Mayordoma JI, Zorina T, Storkus WJ, et al. Bone marrow-derived dendritic cells pulsed with synthetic tumor peptides elicit protective and therapeutic antitumor immunity. Nature Med 1995; 1: 1297-1302.

206. Celuzi CM, Mayordomo JI, Storkus WJ, Lotze MT, Falo LD. Peptide-pulsed dendritic cells induce antigen-specific, cytotoxic T-lymphocyte-mediated protective immunity. J Exp Med 1996; 183: 283-287.

207. Zitvogel L, Mayordomo JI, Tjandrawan T, et al. Therapy of murine tumors with tumor peptide-pulsed dendritic cells: dependence of T-cells, B7 co-stimulation, and T-helper cell 1-associated cytokines. J Exp Med 1996; 183: 87-97.

208. Coulie P, Somville M, Lehmann F, et al. Precursor frequency analysis of human cytolytic lymphocytes directed against autologous melanoma cells. Int $J$ Cancer 1992; 50: 289-297.

209. Doyle A, Martin WJ, Funa K, et al. Markedly decreased expression of class I histocompatibility antigens, protein and mRNA in human small-cell lung cancer. $J$ Exp Med 1985; 161: 1135-1151.

210. Restifo NP, Esquivel F, Kawakami Y, et al. Identification of human cancers deficient in antigen processing. $J$ Exp Med 1993; 177: 265-272.

211. Korkolopoulou P, Kaklamanis L, Pezzella F, Harris AL, Gatter KC. Loss of antigen-presenting molecules (MHC class I and TAP-1) in lung cancer. Br J Cancer 1996; 73: $148-153$.

212. Ljunggren HG, Kärre K. In search of the "missing self": MHC molecules and NK cell recognition. Immunol Today 1990; 11(7): 237-244. 